\title{
Particulate pollutants in the Brazilian city of São Paulo: 1-year investigation for the chemical composition and source apportionment
}

\author{
Guilherme Martins Pereira ${ }^{1,4}$, Kimmo Teinilä ${ }^{2}$, Danilo Custódio ${ }^{1,3}$, Aldenor Gomes Santos ${ }^{4,5,6}$, Huang Xian ${ }^{7}$, \\ Risto Hillamo $^{2}$, Célia A. Alves ${ }^{3}$, Jailson Bittencourt de Andrade ${ }^{4,5,6}$, Gisele Olímpio da Rocha ${ }^{4,5,6}$, Prashant Kumar ${ }^{8,9}$, \\ Rajasekhar Balasubramanian ${ }^{7}$, Maria de Fátima Andrade ${ }^{10}$, and Pérola de Castro Vasconcellos ${ }^{1,4}$ \\ ${ }^{1}$ Institute of Chemistry, University of São Paulo, São Paulo - SP, 05508-000, Brazil \\ ${ }^{2}$ Finnish Meteorological Institute, P.O. Box 503, 00101 Helsinki, Finland \\ ${ }^{3}$ CESAM \& Department of Environment, University of Aveiro, Aveiro, 3810-193, Portugal \\ ${ }^{4}$ INCT for Energy and Environment, Federal University of Bahia, Salvador - BA, 40170-115, Brazil \\ ${ }^{5}$ CIEnAm, Federal University of Bahia, Salvador - BA, 40170-115, Brazil \\ ${ }^{6}$ Institute of Chemistry, Federal University of Bahia, Salvador - BA, 40170-115, Brazil \\ ${ }^{7}$ Department of Civil and Environmental Engineering, National University of Singapore, E1A 07-03, 117576, Singapore \\ ${ }^{8}$ Global Centre for Clean Air Research (GCARE), Department of Civil and Environmental Engineering, \\ Faculty of Engineering and Physical Sciences, University of Surrey, Guildford GU2 7XH, UK \\ ${ }^{9}$ Environmental Flow Research Centre, Faculty of Engineering and Physical Sciences, \\ University of Surrey, Guildford GU2 7XH, UK \\ ${ }^{10}$ Institute of Astronomy, Geophysics and Atmospheric Sciences, University of São Paulo, São Paulo - SP, 05508-090, Brazil
}

Correspondence to: Guilherme Martins Pereira (martinspereira2@hotmail.com)

Received: 4 April 2017 - Discussion started: 21 April 2017

Revised: 25 August 2017 - Accepted: 28 August 2017 - Published: 9 October 2017

\begin{abstract}
São Paulo in Brazil has relatively relaxed regulations for ambient air pollution standards and often experiences high air pollution levels due to emissions of particulate pollutants from local sources and long-range transport of air masses impacted by biomass burning. In order to evaluate the sources of particulate air pollution and related health risks, a year-round sampling was done at the University of São Paulo campus (20 m a.g.l.), a green area near an important expressway. The sampling was performed for $\mathrm{PM}_{2.5}$ $(\leq 2.5 \mu \mathrm{m})$ and $\mathrm{PM}_{10}(\leq 10 \mu \mathrm{m})$ in 2014 through intensive (everyday sampling in wintertime) and extensive campaigns (once a week for the whole year) with $24 \mathrm{~h}$ of sampling. This year was characterized by having lower average precipitation compared to meteorological data, and high-pollution episodes were observed all year round, with a significant increase in pollution level in the intensive campaign, which was performed during wintertime. Different chemical constituents, such as carbonaceous species, polycyclic aromatic hydrocarbons (PAHs) and derivatives, water-soluble ions,
\end{abstract}

and biomass burning tracers were identified in order to evaluate health risks and to apportion sources. The species such as PAHs, inorganic and organic ions, and monosaccharides were determined using chromatographic techniques and carbonaceous species using thermal-optical analysis. Trace elements were determined using inductively coupled plasma mass spectrometry. The risks associated with particulate matter exposure based on PAH concentrations were also assessed, along with indexes such as the benzo[ $a]$ pyrene equivalent (BaPE) and lung cancer risk (LCR). High BaPE and LCR were observed in most of the samples, rising to critical values in the wintertime. Also, biomass burning tracers and PAHs were higher in this season, while secondarily formed ions presented low variation throughout the year. Meanwhile, vehicular tracer species were also higher in the intensive campaign, suggesting the influence of lower dispersion conditions in that period. Source apportionment was performed using positive matrix factorization (PMF), which indicated five different factors: road dust, industrial emissions, vehicu- 
lar exhaust, biomass burning and secondary processes. The results highlighted the contribution of vehicular emissions and the significant input from biomass combustion in wintertime, suggesting that most of the particulate matter is due to local sources, in addition to the influence of pre-harvest sugarcane burning.

\section{Introduction}

Air pollution caused by atmospheric particulate matter (PM) is one of the major environmental problems encountered in Latin American cities such as São Paulo (Brazil), Mexico City (Mexico), Bogotá (Colombia) and Santiago (Chile) (Romero-Lankao et al., 2013; Vasconcellos et al., 2010, 2011a; Villalobos et al., 2015). The air pollution thresholds in most of the Latin American cities are not very stringent compared to international standards or guidelines (Alvarez et al., 2013; Kumar et al., 2016). Several studies have highlighted a statistical relation between PM and health problems, including respiratory and cardiovascular diseases and genotoxic risks (Newby et al., 2015; de Oliveira Alves et al., 2014; Pope, 2000). In this context, $\mathrm{PM}_{2.5}$ (PM with an aerodynamic diameter smaller than $2.5 \mu \mathrm{m})$ and $\mathrm{PM}_{10}$ (PM with an aerodynamic diameter smaller than $10 \mu \mathrm{m}$ ) are particles that are able to penetrate the respiratory system, with $\mathrm{PM}_{2.5}$ reaching alveoli in the lungs, and induce adverse impacts on human health (Cai et al., 2015; Kumar et al., 2014). The elderly and the children are more susceptible to the health effects resulting from $\mathrm{PM}_{2.5}$ (Cançado et al., 2006; Segalin et al., 2017). Considering that the elderly population has grown in São Paulo over the last decades (SEADE, 2016; Segalin et al., 2017), the PM health-related issues can become more relevant. PM also plays an important role in ecosystem biogeochemistry, the hydrological cycle, cloud formation and atmospheric circulation (Pöschl, 2005).

Carbonaceous species such as organic and elemental carbon (OC and EC) represent a large fraction of PM and play an important role in the formation of haze, interaction with climate and adverse human health effects (Bisht et al., 2015; Liu et al., 2016; Seinfeld and Pandis, 2006). Water-soluble ions (WSIs) account for another major fraction of aerosols in urban areas and are able to affect visibility, particle hygroscopicity and cloud formation; they also influence acidity in rainwater and impact climate (Cheng et al., 2011; Jung et al., 2009; Khoder and Hassan, 2008; Tan et al., 2009; Tang et al., 2016; Yang et al., 2015).

Particulate organic carbon includes key species including polycyclic aromatic hydrocarbons (PAHs) and monosaccharides. The last are considered biomass burning tracers (such as levoglucosan, mannosan and galactosan) (Simoneit et al., 1999). PAHs have natural sources (synthesis by plants and bacteria, degradation of plants, forest fires, and volcanic emissions) but are mostly emitted by anthropogenic sources at urban sites (such as domestic, mobile, industrial and agricultural sources) (Abdel-shafy and Mansour, 2016; Ravindra et al., 2008). They have been studied because of their carcinogenic properties (de Oliveira Alves et al., 2014; Seinfeld and Pandis, 2006). The nitrated and oxygenated PAHs (nitroand oxy-PAHs) are emitted as primary species or are formed in situ as secondary compounds (Kojima et al., 2010; Souza et al., 2014b; Zhou and Wenger, 2013; Zimmermann et al., 2013). They are potentially more mutagenic and/or carcinogenic than their PAH precursors (Franco et al., 2010).

Chemical speciation and PAH risk assessment have been performed at several Latin American sites, specifically in urban São Paulo, Bogotá, Buenos Aires (Vasconcellos et al., 2011a, b) and forested areas such as the Amazon region (de Oliveira Alves et al., 2015). Biomass burning tracers have been detected in high concentrations in São Paulo during the dry season and are attributed to the long-range transport of aerosols from areas affected by sugarcane burning. Source apportionment studies have been carried out in São Paulo (Table 1) in the last 3 decades, but not in as much detail as in other megacities. Detailed characterization of the organic fraction of aerosols is still scarce.

A previous study performed in São Paulo in 1989 highlights the relative importance of the emissions from residual oil and diesel in $\mathrm{PM}_{2.5}$ and soil dust in the coarse grain size (Andrade et al., 1994). Da Rocha et al. (2012) studied the emission sources of fuel and biomass burning, the gas-to-particle conversion, and sea spray emissions in PM in São Paulo, in a 1-year period (between 2003 and 2004). Another study conducted in the winter of 2003 pointed out a strong impact of local sources at three sites in the state of São Paulo, in addition to the influence of remote sources (Vasconcellos et al., 2007). A source apportionment for PAHs in the winter of 2002 reported a predominance of diesel emissions for the polyaromatics in $\mathrm{PM}_{2.5}$ (Bourotte et al., 2005). In turn, Castanho and Artaxo (2001), in their study of 1997 and 1998 in São Paulo city, reported no significant differences in the main air pollution sources (i.e., automobile traffic and soil dust) between wintertime and summertime. The main sources for $\mathrm{PM}_{2.5}$ were automobile traffic and soil dust. However, biomass burning was not considered as a potential source by the authors.

The current study presents a more comprehensive study that should lead to a better understanding of the main PM sources and atmospheric processes occurring in the São Paulo megacity than previous studies reported in the literature. A year of extensive sampling of aerosol $\left(\mathrm{PM}_{2.5}\right.$ and $\mathrm{PM}_{10}$ ) and an intensive wintertime campaign were performed. Different classes of chemical components in PM were determined such as carbonaceous species, WSIs, monosaccharides, PAHs and their derivatives. Meteorological data were also collected during the sampling days. Moreover, the benzo $[a]$ pyrene equivalent (BaPE) and lung cancer risk (LCR) indexes were calculated in order to assess the potential toxicity of PAHs. Positive matrix factorization (PMF) 
Table 1. Results of previous source apportionment studies in São Paulo city.

\begin{tabular}{|c|c|c|c|c|c|c|}
\hline Site & Year & Instruments & Species & Range & Identified sources & Source \\
\hline \multirow[t]{2}{*}{$\begin{array}{l}\text { University of São } \\
\text { Paulo - } \\
\text { Atmospheric } \\
\text { Sciences } \\
\text { Department } \\
\text { (campus) }\end{array}$} & \multirow[t]{2}{*}{1989 (winter) } & \multirow[t]{2}{*}{ PIXE } & \multirow[t]{2}{*}{ Elements } & $\mathrm{PM}_{2.5}$ & $\begin{array}{l}\text { Factor analysis - five sources: } \\
\text { industrial emissions }(13 \%) \text {, emis- } \\
\text { sions from residual oil and diesel } \\
(41 \%) \text {, resuspended soil dust }(28 \%) \\
\text { and emissions of } \mathrm{Cu} \text { and } \mathrm{Mg}(18 \%) \text {. }\end{array}$ & \multirow[t]{2}{*}{$\begin{array}{l}\text { Andrade et al. } \\
\text { (1994) }\end{array}$} \\
\hline & & & & $\mathrm{PM}_{2.5-15}$ & $\begin{array}{l}\text { Four sources: soil dust }(59 \%) \text {, } \\
\text { industrial emissions }(19 \%) \text {, oil burn- } \\
\text { ing }(8 \%) \text { and sea salt aerosol }(14 \%) \text {. }\end{array}$ & \\
\hline $\begin{array}{l}\text { University of São } \\
\text { Paulo - } \\
\text { Medicine School } \\
\text { (downtown) }\end{array}$ & 1994 (winter) & $\begin{array}{l}\text { PIXE, } \\
\text { reflectance }\end{array}$ & $\begin{array}{l}\text { Elements, } \\
\text { black } \\
\text { carbon }\end{array}$ & $\mathrm{PM}_{2}$ & $\begin{array}{l}\text { Factor analysis - five sources: } \\
\text { vehicles, garbage incineration, vege- } \\
\text { tation, suspended soil dust and burn- } \\
\text { ing of fuel oil. }\end{array}$ & $\begin{array}{l}\text { Sánchez- } \\
\text { Ccoyllo and } \\
\text { Andrade (2002) }\end{array}$ \\
\hline \multirow[t]{2}{*}{$\begin{array}{l}\text { University of São } \\
\text { Paulo - } \\
\text { Medicine School } \\
\text { building and } \\
\text { Atmospheric } \\
\text { Sciences } \\
\text { Department }\end{array}$} & \multirow[t]{2}{*}{$\begin{array}{l}1997 \\
\text { (winter) and } \\
1998 \text { (summer) }\end{array}$} & \multirow[t]{2}{*}{$\begin{array}{l}\text { TEOM; PIXE; } \\
\text { ACPM; } \\
\text { Aethalome- } \\
\text { ter }\end{array}$} & \multirow[t]{2}{*}{$\begin{array}{l}\text { OC, EC, el- } \\
\text { ements and } \\
\text { gaseous } \\
\text { species }\end{array}$} & $\mathrm{PM}_{2.5}$ & $\begin{array}{l}\text { Factor analysis - five sources: } \\
\text { motor vehicle ( } 28 \text { and } 24 \% \text {, for win- } \\
\text { ter and summer), resuspended soil } \\
\text { dust }(25 \text { and } 30 \%) \text {, oil combustion } \\
\text { source }(18 \text { and } 21 \%) \text {, sulfates ( } 23 \\
\text { and } 17 \%) \text { and industrial emissions ( } 5 \\
\text { and } 6 \%) \text {. }\end{array}$ & \multirow[t]{2}{*}{$\begin{array}{l}\text { Castanho and } \\
\text { Artaxo (2001) }\end{array}$} \\
\hline & & & & $\mathrm{PM}_{2.5-10}$ & $\begin{array}{l}\text { Resuspended soil dust represented a } \\
\text { large fraction }(75-78 \%) \text {. }\end{array}$ & \\
\hline \multirow[t]{2}{*}{$\begin{array}{l}\text { University of São } \\
\text { Paulo - } \\
\text { Atmospheric } \\
\text { Sciences } \\
\text { Department }\end{array}$} & \multirow[t]{2}{*}{2002 (winter) } & \multirow[t]{2}{*}{ GC-MS } & \multirow[t]{2}{*}{ PAHs } & $\mathrm{PM}_{2.5}$ & $\begin{array}{l}\text { Factor analysis - four factors: } \\
\text { diesel emissions, stationary combus- } \\
\text { tion source, vehicular emissions, nat- } \\
\text { ural gas combustion and biomass } \\
\text { burning. }\end{array}$ & \multirow[t]{2}{*}{$\begin{array}{l}\text { Bourotte et al. } \\
(2005)\end{array}$} \\
\hline & & & & $\mathrm{PM}_{2.5-10}$ & $\begin{array}{l}\text { Two factors: vehicular emissions and } \\
\text { mixture of combustion sources (nat- } \\
\text { ural gas combustion, incineration } \\
\text { emissions and oil combustion). }\end{array}$ & \\
\hline $\begin{array}{l}\text { University of São } \\
\text { Paulo - } \\
\text { Atmospheric } \\
\text { Sciences } \\
\text { Department }\end{array}$ & 2003 (winter) & IC; ICPMS & $\begin{array}{l}\text { WSI and } \\
\text { elements }\end{array}$ & $\mathrm{PM}_{10}$ & $\begin{array}{l}\text { Principal component analysis - } \\
\text { two factors ( } 48.5 \% \text { of variance): lo- } \\
\text { cal and remote sources. }\end{array}$ & $\begin{array}{l}\text { Vasconcellos et } \\
\text { al. (2007) }\end{array}$ \\
\hline $\begin{array}{l}\text { University of São } \\
\text { Paulo- } \\
\text { Atmospheric Sci- } \\
\text { ences } \\
\text { Department }\end{array}$ & $\begin{array}{l}2003-2004 \\
\text { (year round) }\end{array}$ & IC; CCD ICP & $\begin{array}{l}\text { WSI and el- } \\
\text { ements }\end{array}$ & $\mathrm{PM}_{10}$ & $\begin{array}{l}\text { Principal component analysis - } \\
\text { three principal components: biomass } \\
\text { burning and/or automobile fuel burn- } \\
\text { ing }(40.3 \%) \text {, gas-to-particle conver- } \\
\text { sion }(12.7 \%) \text { and sea spray contribu- } \\
\text { tion }(11.7 \%) \text {. }\end{array}$ & $\begin{array}{l}\text { da Rocha et al. } \\
\text { (2012) }\end{array}$ \\
\hline $\begin{array}{l}\text { University of São } \\
\text { Paulo - } \\
\text { Medicine School } \\
\text { building }\end{array}$ & $\begin{array}{l}\text { 2007-2008 } \\
\text { (year round) }\end{array}$ & $\begin{array}{l}\text { X-ray } \\
\text { spectrometry, } \\
\text { reflectance }\end{array}$ & $\begin{array}{l}\text { Elements } \\
\text { and black } \\
\text { carbon }\end{array}$ & $\mathrm{PM}_{2.5}$ & $\begin{array}{l}\text { APCA - four factors: crustal emis- } \\
\text { sion (soil and construction) }(13 \%) \text {; } \\
\text { oil-burning boilers, industrial emis- } \\
\text { sions and secondary aerosol forma- } \\
\text { tion }(13 \%) \text {; light-duty vehicle emis- } \\
\text { sions }(12 \%) \text { and heavy-duty diesel } \\
\text { fleet }(28 \%) \text {. }\end{array}$ & $\begin{array}{l}\text { Andrade et al. } \\
\text { (2012) }\end{array}$ \\
\hline
\end{tabular}




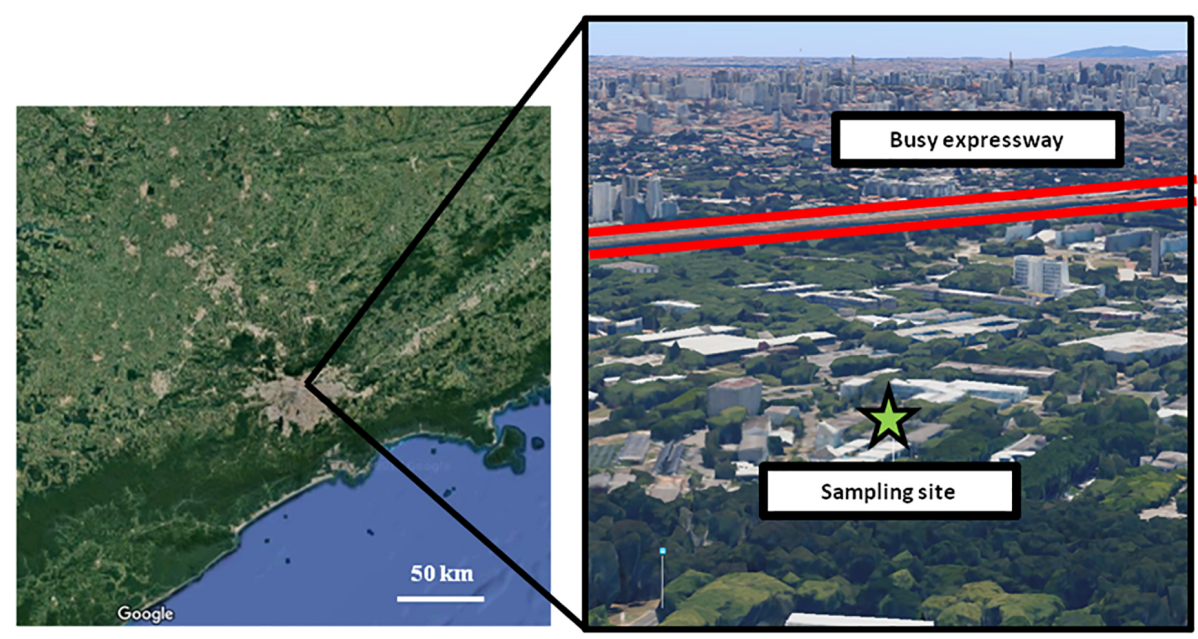

Figure 1. Location of the sampling site. Maps are a courtesy of Google Maps.

analysis was also used for the source apportionment of $\mathrm{PM}_{10}$ during the extensive campaign.

\section{Methodology}

\subsection{Sampling campaigns}

Aerosol samples were collected at a São Paulo site (SPA, $23^{\circ} 33^{\prime} 34^{\prime \prime} \mathrm{S}$ and $46^{\circ} 44^{\prime} 01^{\prime \prime} \mathrm{W}$ ) located on the rooftop of the Atmospheric Sciences Department (about $20 \mathrm{~m}$ a.g.l.), at the Institute of Astronomy, Geophysics and Atmospheric Sciences (IAG-USP) building, within the campus of the University of São Paulo. The location is inside a green area and approximately $2 \mathrm{~km}$ away from an important expressway (Marginal Pinheiros) (Fig. 1). Aerosols were collected in intensive (every day) and extensive campaigns (once a week) throughout 2014. Firstly, the extensive campaign was performed weekly. Accordingly, samples were collected every Tuesday for $\mathrm{PM}_{2.5}$ (termed $\mathrm{Ext}_{2.5}$ in this study) and $\mathrm{PM}_{10}$ (termed Ext 10 ). However, due to equipment breaking down, the $\mathrm{PM}_{2.5}$ sampling was stopped in September while the $\mathrm{PM}_{10}$ sampling continued until December $(n=32$ and 38 , respectively). Secondly, the intensive campaign (termed $\left.\mathrm{Int}_{2.5}\right)$ took place between 1 and 18 July $2014(n=12)$, only for $\mathrm{PM}_{2.5}$ due to problems with $\mathrm{PM}_{10}$ equipment. However, there were 4 days (between 8 and 11 July) for which data were not collected due to heavy rain.

PM samples were collected for a period of $24 \mathrm{~h}$, with high-volume air samplers (HiVol), with a flow rate of $1.13 \mathrm{~m}^{3} \mathrm{~min}^{-1}$, with 2.5 and $10 \mu \mathrm{m}$ size selective inlets (Thermo Andersen, USA). Prior to sampling, quartz fiber filters $(20 \mathrm{~cm} \times 25 \mathrm{~cm}$, Millipore, USA) were baked for $8 \mathrm{~h}$ at $800^{\circ} \mathrm{C}$ to remove the organics. In addition, filters were equilibrated at room temperature and weighed in a microbalance before and after the sampling in order to estimate the PM concentration. After sampling and weighing, the filters were wrapped in aluminum foil and stored in a refrigerator at $5{ }^{\circ} \mathrm{C}$ until chemical analyses were performed.

\subsection{Meteorological data}

The meteorological data (ambient temperature, relative humidity, precipitation and wind speed) were collected from the climatological bulletin of the IAG-USP meteorological station (IAG, 2014). The climate of São Paulo is often classified as humid subtropical (Andrade et al., 2012a). The wintertime in the city is characterized by a slight decrease in temperatures, together with considerably lower relative humidity and precipitations, with more thermodynamic stability, often resulting in accumulation of air pollutants in the lower troposphere, and is also subjected to thermal inversion episodes (Miranda et al., 2012). The local air circulation is mainly associated with the Atlantic Ocean breeze and cold fronts in wintertime often intensify that, with winds generally coming from the southeast (Vasconcellos et al., 2003). In Fig. S1 in the Supplement a comparison between the average climatological temperature and the data for 2014 is presented (IAG, 2014). During the 2014 campaign, the summer was atypically warmer and drier.

In order to analyze the long-range transport of air pollutants, backward air mass trajectories $(96 \mathrm{~h})$ were run using the HYSPLIT model (Draxler and Rolph, 2003), through the READY (Real-time Environmental Applications and Display sYstem) platform from NOAA. The heights considered were 500,1500 and $3000 \mathrm{~m}$, corresponding to trajectories near the ground, upper boundary layer and low free troposphere, respectively (Cabello et al., 2016; Toledano et al., 2009). 
Table 2. Details of the analyzed species, analytical methods and detection limits.

\begin{tabular}{|c|c|c|}
\hline Analytical method & Detection limits $\left(\mathrm{ng} \mathrm{m}^{-3}\right)$ & Determined species \\
\hline Thermal-optical analysis & $0.01-0.06$ & 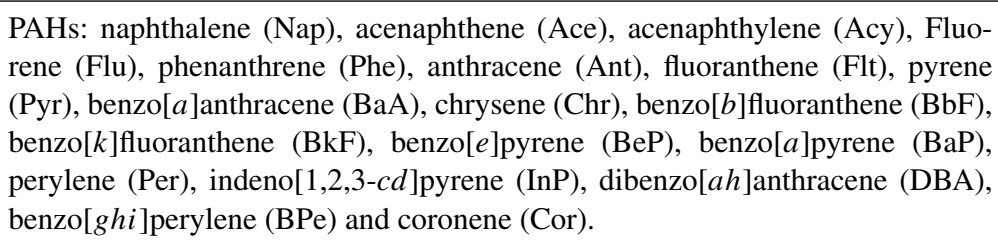 \\
\hline \multirow[t]{2}{*}{ GC-MS } & $0.01-0.50$ & $\begin{array}{l}\text { Nitro-PAHs: (1-nitronaphthalene (1-NNap), 2-nitronaphthalene (2-NNap), } \\
\text { 1-methyl-4-nitronaphthalene (1-Methyl-4-NNap), 1-methyl-5-nitronaphthalene } \\
\text { (1-Methyl-5-NNap), 1-methyl-6-nitronaphthalene (1-Methyl-6-NNap), 2- } \\
\text { methyl-4-nitronaphthalene (2- methyl-4-NNap), 2-nitrobiphenyl (2-NBP), } \\
\text { 3-nitrobiphenyl (3-NBP), 4-nitrobiphenyl (4-NBP), 5-nitroacenaphthene } \\
\text { (5-NAce), 2-nitrofluorene (2-Nflu), 2-nitrophenanthrene (2-NPhe), 3- } \\
\text { nitrophenanthrene (3-NPhe), 9-nitrophenanthrene (9-NPhe), 2-nitroanthracene } \\
\text { (2-NAnt), 9-nitroanthracene (9-NAnt), 2-nitrofluoranthene (2-NFlt), 3- } \\
\text { nitrofluoranthene (3-NFlt), 1-nitropyrene (1-NPyr), 2-nitropyrene (2-NPyr), } \\
\text { 4-nitropyrene (4-NPyr), 6-nitrochrysene (6-NChr), 7-nitrobenz[a]anthracene } \\
\text { (7-NBaA), 3-nitrobenzanthrone (3- NBA), 6-nitrobenzo[a]pyrene (6-NBaPyr), } \\
\text { 1-nitrobenzo[e]pyrene (1-NBePyr), and 3-nitrobenzo[e]pyrene (3-NBePyr). }\end{array}$ \\
\hline & $0.3-10.3$ & $\begin{array}{l}\text { Oxy-PAHs: 1,4-benzoquinone (1,4-BQ), 9,10-phenanthraquinone }(9,10- \\
\text { PQ), 9,10-anthraquinone }(9,10-\mathrm{AQ}), \text { 1,2-naphthoquinone }(1,2-\mathrm{NQ}) \text { and } \\
\text { 1,4-naphthoquinone }(1,4-\mathrm{NQ}) \text {. }\end{array}$ \\
\hline IC & $1.3-1.3$ & $\begin{array}{l}\text { WSI: } \mathrm{Cl}^{-}, \mathrm{NO}_{3}^{-}, \mathrm{SO}_{4}^{2-}, \mathrm{C}_{2} \mathrm{O}_{4}^{2-} \text {, methylsulfonate }\left(\mathrm{MSA}^{-}\right), \mathrm{Na}^{+}, \mathrm{K}^{+} \text {, and } \\
\mathrm{NH}_{4}^{+} \text {. }\end{array}$ \\
\hline HPAEC-MS & $1.3-2.5$ & Monosaccharides: levoglucosan (Lev), mannosan (Man) and galactosan (Gal). \\
\hline
\end{tabular}

\subsection{Analytical procedures, reagents and standards}

After sampling, the filters were punched for the chemical analysis, as shown in Table 2, which lists all substances determined and their respective analytical techniques as well as their detection limits (DLs).

Carbonaceous species were determined at the University of Aveiro, with two punches of $9 \mathrm{~mm}$ diameter. Firstly, the carbonates were removed with hydrochloric acid fumes and then OC and EC were determined using a thermal-optical transmission equipment developed at the university. The system comprises a quartz tube with two heating zones, a pulsed laser and a nondispersive infrared $\mathrm{CO}_{2}$ analyzer (NDIR). The filters were placed into the first heating zone of the quartz tube then heated to $600^{\circ} \mathrm{C}$ in a nitrogen atmosphere for the organic fraction to vaporize, which was quantified as OC. EC was determined with a sequential heating at $850^{\circ} \mathrm{C}$ in an atmosphere containing $4 \% \mathrm{O}_{2}$. The other heating zone was filled with cupric oxide and was maintained at $650{ }^{\circ} \mathrm{C}$ in a $4 \% \mathrm{O}_{2}$ atmosphere to assure that all carbon was oxidized to
$\mathrm{CO}_{2}$, which was quantified using a NDIR analyzer (Alves et al., 2015).

The determination of polycyclic aromatic hydrocarbons and their derivatives was performed at the Federal University of Bahia, Brazil, and is summarized in Table 2. Briefly, samples were extracted for $23 \mathrm{~min}$ in an ultrasonic bath $\left(4.2 \mathrm{~cm}^{2}\right.$ punches) with a $500 \mu \mathrm{L}$ solution of $18 \%$ of acetonitrile in dichloromethane, employing miniaturized extraction devices (Whatman Mini ${ }^{\mathrm{TM}}$ UniPrep Filters, Whatman, USA). Their quantification was carried out using gas chromatography with high-resolution mass spectrometer detection (GCMS). The procedure is described in more detail in Santos et al. (2016). BeP was quantified with the same calibration curve as $\mathrm{BaP}$ since they have a similar fragmentation pattern in the MS detector (Robbat and Wilton, 2014).

The US Environmental Protection Agency (EPA) 610 PAH mix in methanol: dichloromethane $(1: 1)$, containing $2000 \mu \mathrm{g} \mathrm{mL}^{-1}$ each, was purchased from Supelco (St. Louis, USA). Individual standards of $50 \mu \mathrm{g} \mathrm{mL}^{-1}$ coronene (Cor) and $1000 \mu \mathrm{g} \mathrm{mL}^{-1}$ perylene (Per) and two deuterated compounds, pyrene D10 (Pyr d10) and fluorene D10 (Flu 
d10), were purchased from Sigma-Aldrich (St. Louis, USA). Quinones investigated in this study were purchased from Fluka (St. Louis, USA). Nitro-PAH certified standard solutions SRM 2264 (aromatic hydrocarbons nitrated in methylene chloride I) and SRM 2265 (polycyclic aromatic hydrocarbons nitrated in methylene chloride II) were purchased from the National Institute of Standards and Technology (NIST, USA).

Monosaccharides and WSIs were determined at the Finnish Meteorological Institute. From quartz fiber filter samples, $1 \mathrm{~cm}^{2}$ filter pieces were punched for both analyses. Concentrations of monosaccharides were determined using a Dionex ICS-3000 system coupled to a quadrupole mass spectrometer (Dionex $\mathrm{MSQ}^{\mathrm{TM}}$ ) using highperformance anion exchange chromatography (HPAECMS). Levoglucosan (1,6-anhydro- $\beta$-D-glucopyranose, purity $99 \%$; Acros Organics, NJ, USA), mannosan (1,6-anhydro$\beta$-D-mannopyranose, purity $99 \%$; Sigma-Aldrich Co., MO, USA) and galactosan (1,6-anhydro- $\beta$-D-galactopyranose; Sigma-Aldrich Co.) were used for the calibration. The $1 \mathrm{~cm}^{2}$ punches were extracted with $5 \mathrm{~mL}$ of deionized water (MilliQ water; resistivity $18.2 \mathrm{M} \Omega \mathrm{cm}$ at $25^{\circ} \mathrm{C}$; Merck Millipore, MA, USA), with methyl- $\beta$-D-arabinopyranoside as the internal standard (purity $99 \%$; Aldrich Chemical Co., WI, USA) and $10 \mathrm{~min}$ of gentle rotation. The extract was filtered through an IC Acrodisc ${ }^{\circledR}$ syringe filter $(13 \mathrm{~mm}, 0.45 \mu \mathrm{m}$ Supor $^{\circledR}$ (PES) membrane, Pall Sciences) (Saarnio et al., 2010).

In order to determine the WSIs $\left(\mathrm{Cl}^{-}, \mathrm{NO}_{3}^{-}, \mathrm{SO}_{4}^{2-}, \mathrm{C}_{2} \mathrm{O}_{4}^{2-}\right.$, methylsulfonate, $\mathrm{Na}^{+}, \mathrm{K}^{+}, \mathrm{NH}_{4}^{+}$), $10 \mathrm{~mL}$ of deionized water was used to extract the sample aliquots, with $10 \mathrm{~min}$ of gentle rotation. The ions were determined using two ion chromatography systems (ICS 2000 system, Dionex) simultaneously; cations were analyzed using a CG12A/CS12A column with an electrochemical suppressor (CSRS ULTRA II, $4 \mathrm{~mm}$ ) and anions using an AG11/AS11 column with an electrochemical suppressor (ASRS ULTRA II, $4 \mathrm{~mm}$ ).

Finally, trace elements in the samples were extracted using a microwave digestion system (MLS-1200 mega, Milestone Inc., Italy) at the National University of Singapore. Punches of the filters were cut into small pieces and added into PTFE vessels with $4 \mathrm{~mL} \mathrm{HNO}_{3}$ (Merck), $2 \mathrm{~mL} \mathrm{H}_{2} \mathrm{O}_{2}$ (Merck) and $0.2 \mathrm{~mL}$ HF (Merck). The vessels were then subjected to a three-stage digestion inside the microwave digester $(250 \mathrm{~W}$ for $5 \mathrm{~min}, 400 \mathrm{~W}$ for $5 \mathrm{~min}$, and $600 \mathrm{~W}$ for $2 \mathrm{~min}$ ). Following the digestion procedure, extracts were filtered with $0.45 \mu \mathrm{m}$ PTFE syringe filters, diluted eight times and stored in the $4^{\circ} \mathrm{C}$ cold room. The concentrations of trace elements were quantified using ICP-MS (Agilent 7700, USA) in triplicates. The instrumental parameters maintained during sample runs using the ICP-MS analysis were plasma gas $\left(15.0 \mathrm{~L} \mathrm{~min}^{-1}\right)$, auxiliary gas $\left(1.0 \mathrm{~L} \mathrm{~min}^{-1}\right)$ and nebulizer gas $\left(1.0 \mathrm{~L} \mathrm{~min}^{-1}\right)$. Clean ceramic scissors and forceps were used to handle all PM samples. ICP-MS standards (purchased from HighPurity Standards, USA) were used for calibration.

\subsection{Statistical analysis and receptor model}

Pearson coefficients were calculated to verify the correlation between all the species (software STATISTICA). It determines the extent to which values of the variables are linearly correlated. The coefficients $(r)$ were considered significant when $p<0.05$. Two-tailed $t$ tests were also employed in order to evaluate equal and unequal variances $(p<0.05)$. Polar plots considered the mass concentrations as a function of wind speed and direction (software $\mathrm{R} \times 64$ 3.3.2).

The widely used source apportionment model, PMF, was applied to all sample datasets (Paatero and Tapper, 1994). In this study, specifically, the EPA PMF5.0 software was used. Variables were classified as "strong", "weak" and "bad" according to the signal-to-noise ratio $(\mathrm{S} / \mathrm{N})$, number of samples below the detection limit (Amato et al., 2016; Contini et al., 2016; Paatero and Hopke, 2003) and thermal stability of the species. The species were categorized as bad when the $\mathrm{S} / \mathrm{N}$ ratios were less than 0.2 and weak when the $\mathrm{S} / \mathrm{N}$ ratios were greater than 0.2 but less than 2 (Lang et al., 2015). Accordingly, species with $\mathrm{S} / \mathrm{N}$ ratios higher than 2 were considered strong. Bad variables were excluded from the model and the weak ones had their uncertainty increased by a factor of 3, as described in the EPA PMF Fundamentals and User Guide (Norris et al., 2014).

When concentrations were below the DLs, they were substituted by half the DL. Missing data were replaced by the median $(M)$ of the whole dataset for that species (Brown et al., 2015). Uncertainties were calculated by Eq. (1) according to Norris et al. (2014), when the concentrations were below the detection limits:

$\mathrm{Unc}=5 / 6 \times \mathrm{DL}$.

Uncertainty for missing data (Brown et al., 2015) is given by Eq. (2):

$\mathrm{Unc}=4 \times M$.

When the concentrations were above the detection limit, uncertainty was determined from Eq. (3):

$\mathrm{Unc}=\left([\mathrm{EF} \times C]^{2}+[0.5 \times \mathrm{DL}]^{2}\right)^{1 / 2}$,

where $\mathrm{EF}$ is the error fraction and $C$ is the element concentration. $Q$ robust value $\left(Q_{\mathrm{R}}\right)$ is the goodness-of-fit parameter computed with the exclusion of points not fitted by the model. To evaluate the number of factors, $Q_{\mathrm{R}}$ was compared to $Q_{\mathrm{T}}$ ( $Q$ theoretical value). At the point when changes in the ratio $Q_{\mathrm{R}} / Q_{\mathrm{T}}$ become smaller with the increase of the number of factors, it can be demonstrative that there might be an excessive number of factors being fitted (Brown et al., 2015). $Q_{\mathrm{T}}$ was estimated as in Lang et al. (2015), given by Eq. (4):

$Q_{\mathrm{T}}=\left(n_{s} \times n_{\mathrm{e}}\right)-\left(\left[n_{s} \times n_{\mathrm{f}}\right]+\left[n_{\mathrm{e}} \times n_{\mathrm{f}}\right]\right)$,

where $n_{s}$ is the number of samples, $n_{\mathrm{e}}$ is the number of strong elements and $n_{\mathrm{f}}$ is the number of factors. 

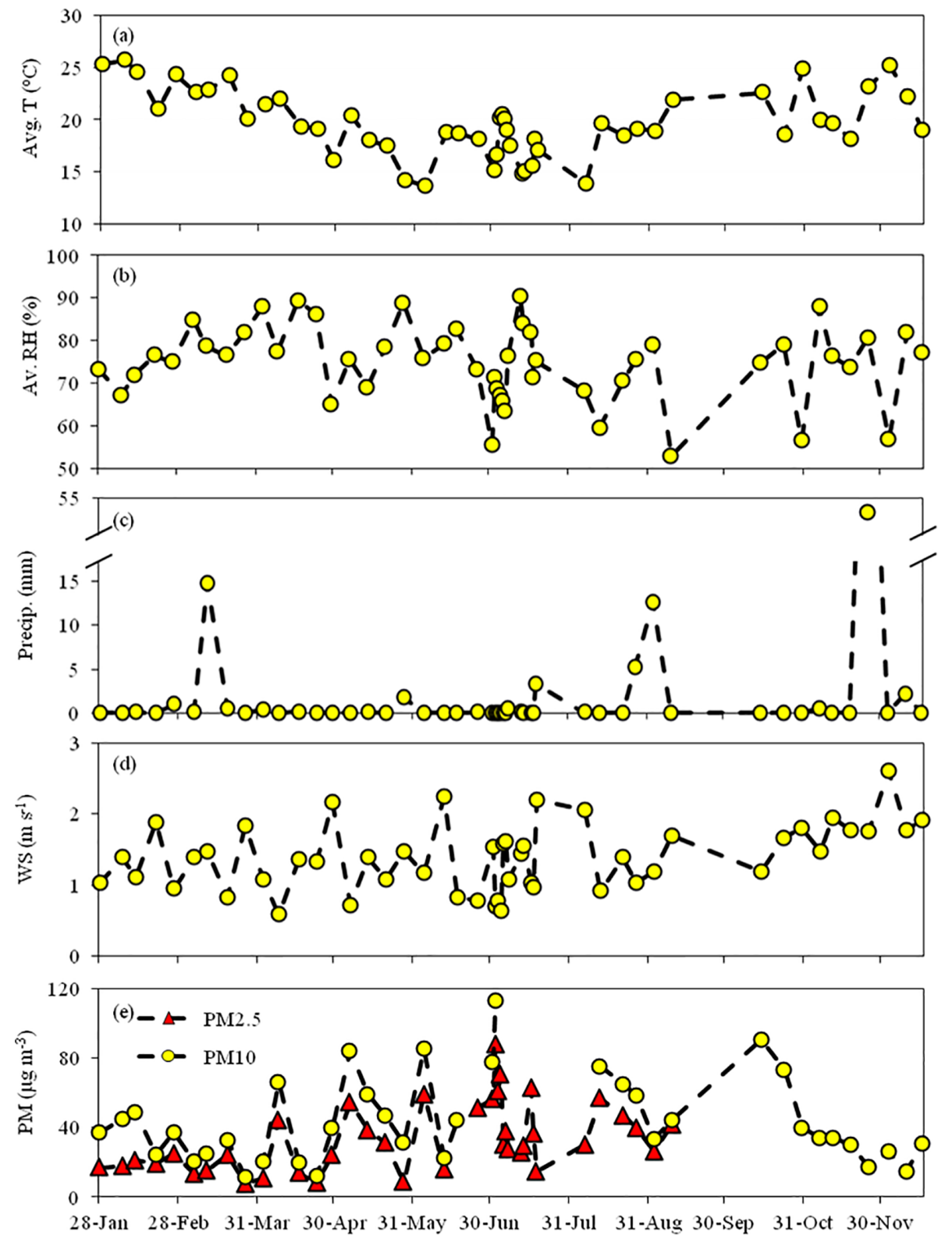

Figure 2. (a) Daily average temperatures, (b) relative humidity (RH), (c) precipitation, (d) wind speed, and (e) $\mathrm{PM}_{10}$ and $\mathrm{PM}_{2.5}$ concentrations for the three campaigns.

\section{Results and discussions}

\subsection{Concentrations of $\mathrm{PM}_{2.5}$ and $\mathrm{PM}_{10}$ during extensive campaigns}

The extensive campaigns $\left(\operatorname{Ext}_{2.5}\right.$ and $\left.\operatorname{Ext}_{10}\right)$ were carried out over a whole year, during which the meteorological conditions varied largely. The average temperature during the sampling days in all campaigns ranged from 14 to $26^{\circ} \mathrm{C}$ and the wind speed varied between 0.6 and $2.6 \mathrm{~m} \mathrm{~s}^{-1}$; most of the sampling was carried out on days without rainfall. In Fig. 2 the meteorological variables $\mathrm{PM}_{10}$ and $\mathrm{PM}_{2.5}$ concentrations for all analyzed days are presented.

There were moderate negative correlations between $\mathrm{PM}_{10}$ and average wind speed, average and minimum relative humidity and between $\mathrm{PM}_{2.5}$ and average wind speed and minimum relative humidity (Table S1 in the Supplement). This observation is in agreement with the fact that days with lower relative humidity and lower wind speed present higher $\mathrm{PM}_{2.5}$ and $\mathrm{PM}_{10}$ levels than in more humid and windier conditions.

In the extensive campaign, the PM mass concentrations exhibited a wide range of concentrations. For example, Ext $_{2.5}$ ranged from 8 to $78 \mu \mathrm{g} \mathrm{m}^{-3}$ (average $30 \mu \mathrm{g} \mathrm{m}^{-3}$ ), 


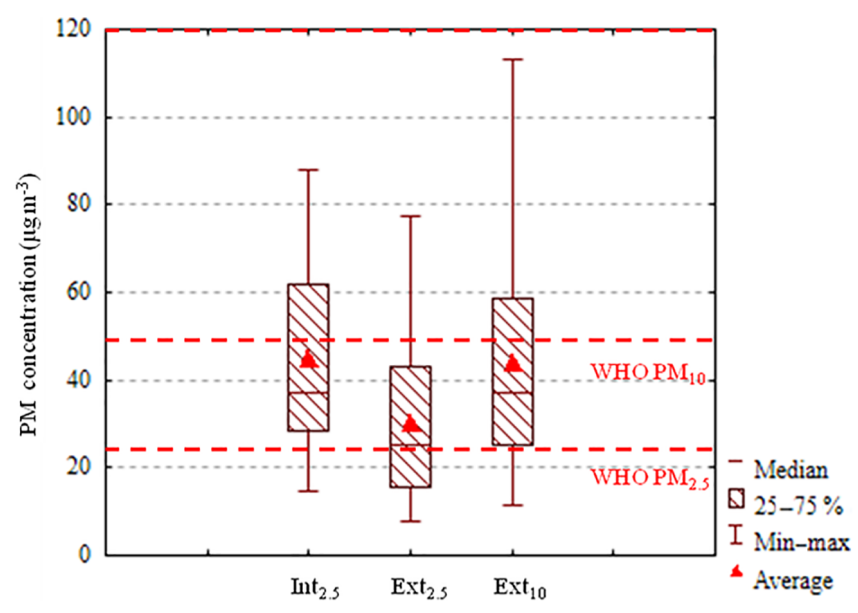

Figure 3. Box plot for particulate matter concentrations in the intensive and extensive campaigns.

whereas $\operatorname{Ext}_{10}$ values varied between 12 and $113 \mu \mathrm{g} \mathrm{m}^{-3}$ (average $44 \mu^{-3} \mathrm{~m}^{-3}$ ) (Fig. 3). The World Health Organization (WHO) recommends a daily limit of $50 \mu \mathrm{g} \mathrm{m}^{-3}$ for $\mathrm{PM}_{10}$ and $25 \mu \mathrm{g} \mathrm{m}^{-3}$ for $\mathrm{PM}_{2.5}$, (WHO, 2006), while the Brazilian environmental agency (CONAMA) recommends a threshold of $150 \mu \mathrm{g} \mathrm{m}^{-3}$ for $\mathrm{PM}_{10}$ (CONAMA, 1990; Pacheco et al., 2017). When considering the CONAMA standards, only 1 day in the extensive campaign was near the target limit. For PM, a coverage of $90 \%$ for 1 calendar year is recommended for a proper risk assessment by the European Union ambient air quality directive, although, often a coverage of $75 \%$ is often adopted (EEA, 2016); the data in this study did not reach these coverages. The Ext 10 campaign was divided into two periods: dry (April-September) and rainy (October-March). It was observed that the average $\mathrm{PM}_{10}$ was $52 \mu \mathrm{g} \mathrm{m}^{-3}$ in the dry period and $35 \mu \mathrm{g} \mathrm{m}^{-3}$ in the rainy period.

A study done by Vasconcellos et al. (2011b) about a decade ago (2003-2004) in the city showed a similar average of $\mathrm{PM}_{10}\left(46 \mu \mathrm{g} \mathrm{m}^{-3}\right)$. According to CETESB (São Paulo state environmental agency), the annual average $\mathrm{PM}_{10}$ concentrations (considering all monitoring stations in the São Paulo metropolitan area) ranged from 33 to $41 \mu \mathrm{g} \mathrm{m}^{-3}$, between the years of 2005 and 2014, showing no significant differences (CETESB, 2015).

The average values for $\mathrm{PM}_{2.5}$ were higher than those obtained in a 1-year study done at traffic sites in two European metropolises: London and Madrid in 2005 (warm period: 19.40 and $20.63 \mu \mathrm{g} \mathrm{m}^{-3}$ for $\mathrm{PM}_{2.5}$, respectively) (Kassomenos et al., 2014). The European Union has a more restrictive control of pollutant emissions compared to Latin American countries since an annual mean of $40 \mu \mathrm{g} \mathrm{m}^{-3}$ is established for $\mathrm{PM}_{10}$ and a limit value of $25 \mu \mathrm{g} \mathrm{m}^{-3}$ is imposed for $\mathrm{PM}_{2.5}$ (Kassomenos et al., 2014). However, these averages in São Paulo are lower than those observed in year-round studies performed in Chinese megacities, such as Shanghai $\left(83 \mu \mathrm{g} \mathrm{m}^{-3}\right.$ for $\mathrm{PM}_{2.5}$ and $123 \mu \mathrm{g} \mathrm{m}^{-3}$ for $\left.\mathrm{PM}_{10}\right)$ and Nanjing $\left(222 \mu \mathrm{g} \mathrm{m}^{-3}\right.$ for $\mathrm{PM}_{2.5}$ and $316 \mu \mathrm{g} \mathrm{m}^{-3}$ for $\mathrm{PM}_{10}$ ) (Shi et al., 2015; Wang et al., 2003; J. Wang et al., 2013). Indeed, in 2014, Zheng et al. (2016) assessed the $\mathrm{PM}_{2.5}$ concentrations in 161 Chinese cities, reporting an annual average concentration of $62 \mu \mathrm{g} \mathrm{m}^{-3}$.

In this study it was found that, on average, more than $60 \%$ of the total mass PM is within the category $\mathrm{PM}_{2.5}$; it is consistent with a previous study performed at this site (dry season, 2008) when this value was $69 \%$ (Souza et al., 2014a). Conversely, in a 2-year study conducted at 10 urban sites in Rio de Janeiro, the coarse fraction represented from 60 to $70 \%$ of the $\mathrm{PM}_{10}$ mass concentration (Godoy et al., 2009). The $\mathrm{PM}_{2.5} / \mathrm{PM}_{10}$ ratio found at other urban Brazilian sites with different characteristics (biomass burning, coastal environment) were close to $40 \%$, considerably lower than in the São Paulo metropolitan area, according to the local environmental agency (CETESB, 2015), highlighting the importance of fine PM in São Paulo city aerosol.

\subsection{Concentrations of $\mathbf{P M}_{2.5}$ during the intensive campaign}

The winter campaign began with high $\mathrm{PM}_{2.5}$ concentrations (a maximum of $88 \mu \mathrm{g} \mathrm{m}^{-3}$ on 2 July) and low relative humidity (minimum of $21 \%$ ). The average temperatures ranged from 15 to $21^{\circ} \mathrm{C}$ and the wind speed ranged between 0.6 and $2.2 \mathrm{~km} \mathrm{~h}^{-1}$. The concentrations of $\mathrm{PM}_{2.5}$ in the intensive campaign ranged from 15 to $88 \mu \mathrm{g} \mathrm{m}^{-3}$ (average $45 \mu \mathrm{g} \mathrm{m}^{-3}$ ), with a similar average to that obtained in another intensive

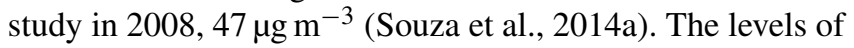
$\mathrm{PM}_{2.5}$ in this campaign were above the levels recommended by $\mathrm{WHO}$ on $90 \%$ of the sampling days.

The average concentration of $\mathrm{PM}_{2.5}$ was higher in $\mathrm{Int}_{2.5}$ than in $\mathrm{Ext}_{2.5}$, which can be explained by the fact that the campaign took place in the dry season (winter). In winter, the meteorological conditions are more unfavorable to the dispersion of pollutants and also due to the predominance of sugarcane burning (da Rocha et al., 2005, 2012; SánchezCcoyllo and Andrade, 2002; Vasconcellos et al., 2010).

\subsection{WSI and trace elements}

The WSIs represent a large fraction in the aerosol mass and have already been suggested to present the ability to form CCN (cloud condensation nuclei) and fog (Rastogi et al., 2014). The secondary inorganic components, sulfate, nitrate and ammonium (SNA), were the most abundant ions in all campaigns (Table 3), which has already been observed in previous studies for this site (Vasconcellos et al., 2011a). SNA accounted for 74, 82 and $79 \%$ of the total mass of inorganic species in the $\mathrm{Int}_{2.5}$, Ext 2.5 and Ext $_{10}$ campaigns, respectively. SNA were also found to be the major portion of the WSIs in other studies around the world. For instance, Zheng et al. (2016) assessed $\mathrm{PM}_{2.5}$ concentrations at 17 diversified sites in China. An average contribution of SNA of 
Table 3. Concentrations of WSI in all campaigns.

\begin{tabular}{lrrr}
\hline & Int $_{2.5}$ & Ext $_{2.5}$ & Ext $_{10}$ \\
\cline { 2 - 4 }$\left(\mathrm{ng} \mathrm{m}^{-3}\right)$ & Average $($ min-max $)$ & Average $($ min-max $)$ & Average (min-max) \\
\hline $\mathrm{Cl}^{-}$ & $964(107-4549)$ & $330(16-1427)$ & $641(76-5904)$ \\
$\mathrm{NO}_{3}^{-}$ & $2678(667-6873)$ & $1430(183-3419)$ & $2872(437-8880)$ \\
$\mathrm{SO}_{4}^{2-}$ & $3266(1252-5959)$ & $3197(922-6300)$ & $3680(569-9361)$ \\
$\mathrm{MSA}^{-}$ & $84(15-214)$ & $63(13-226)$ & $107(28-444)^{*}$ \\
$\mathrm{C}_{2} \mathrm{O}_{4}^{2-}$ & $478(176-753)$ & $282(57-726)$ & $367(50-1180)$ \\
$\mathrm{Na}^{+}$ & $350(46-869)$ & $238(64-512)$ & $571(76-1908)$ \\
$\mathrm{NH}_{4}^{+}$ & $1712(613-4075)$ & $1370(281-2845)$ & $1336(57-4436)$ \\
$\mathrm{Nss}_{-} \mathrm{K}^{+}$ & $809(237-2007)$ & $366(49-1137)$ & $413(63-1181)$ \\
$\mathrm{SNA}^{-}$ & 7655 & 5997 & 7888 \\
\hline $\mathrm{Total}^{2-}$ & 10334 & 7276 & 9986 \\
$\mathrm{SO}_{4}^{2-} / \mathrm{NO}_{3}^{-}$ & 1.2 & 2.2 & 1.3 \\
$\mathrm{Cl}^{-} / \mathrm{Na}^{+}$ & 2.7 & 1.4 & 1.1 \\
\hline $\mathrm{SNA}^{-}$total $(\%)$ & 74 & 82 & 79 \\
\hline
\end{tabular}

* Data were not determined after 21 August.

more than $90 \%$ of total ions was obtained, which represented $50 \%$ of $\mathrm{PM}_{2.5}$. The levels of SNA in aerosols from urban sites are highly influenced by the anthropogenic emissions of precursors $\left(\mathrm{SO}_{2}, \mathrm{NO}_{x}\right.$, and $\mathrm{NH}_{3}$ ) (Y. Wang et al., 2013), although they may also be directly emitted for different sources, such as automobile or industrial sources.

Sulfate average concentrations appear to vary less than nitrate, comparing $\mathrm{Int}_{2.5}$ to $\mathrm{Ext}_{2.5}$, and were not statistically different $(p \sim 0.8)$. The same trend in sulfate in this study was also observed by Villalobos et al. (2015) for Santiago, Chile, in 2013. In that study, the annual average concentration of sulfate $\left(2000 \mathrm{ng} \mathrm{m}^{-3}\right)$ was considerably lower than that observed in extensive São Paulo campaigns in 2014. The sulfate concentrations in Santiago aerosols have been reduced since air quality regulations limited the sulfur content in diesel and gasoline to $15 \mathrm{ppm}$ (MMA, 2014). In Brazil, since 2013 the S-10 diesel (10 ppm of sulfur) was substituted for the S-50 diesel (50 ppm), whereas in 2014 the S50 gasoline replaced the $S-800$ gasoline $(800 \mathrm{ppm})$, although older vehicles are still allowed to use S-500 (500 ppm) diesel (CETESB, 2015). During the studies performed at several urban sites in China, sulfate concentrations varied between 4200 and $23000 \mathrm{ng} \mathrm{m}^{-3}$. These values are higher than those of this study and also 5 to 10 times higher than the measured concentrations in Europe and United States (Hidy, 2009; Putaud et al., 2004; Zheng et al., 2016).

The $\mathrm{SO}_{4}^{2-} / \mathrm{NO}_{3}^{-}$ratio was nearly twice as high in the Ext 2.5 campaign as in Int $_{2.5}$. This pattern has already been observed; in warmer ambient conditions the fine $\mathrm{NO}_{3}^{-}$aerosols can be volatilized, increasing the ratio between these species (Rastogi and Sarin, 2009; Souza et al., 2014a). $\mathrm{NH}_{4} \mathrm{NO}_{3}$ exists in a reversible equilibrium between $\mathrm{HNO}_{3}$ and $\mathrm{NH}_{3}$ (Tang et al., 2016). Ammonium con- centrations were not significantly different $(p \sim 0.3)$ and were slightly higher in $\operatorname{Int}_{2.5}\left(1712 \mathrm{ng} \mathrm{m}^{-3}\right)$ than in $\mathrm{Ext}_{2.5}$ (1370 $\mathrm{ng} \mathrm{m}^{-3}$ ).

Non-sea salt potassium was calculated (nss- $\mathrm{K}^{+}$) based on seawater ion ratios $\left[\mathrm{ss}-\mathrm{K}^{+}\right]=0.036\left[\mathrm{Na}^{+}\right]$(Nayebare et al., 2016; Seinfeld and Pandis, 2006). Concentrations of nss$\mathrm{K}^{+}$were significantly higher in $\mathrm{Int}_{2.5}$ than in $\mathrm{Ext}_{2.5}$, with average concentrations of 809 and $366 \mathrm{ng} \mathrm{m}^{-3}$, respectively $(p<0.01)$. The higher concentrations found in the intensive campaigns have already been attributed to biomass burning in previous studies (Pereira et al., 2017; Vasconcellos et al., 2011a). However, potassium ions can also come from soil resuspension (Ram et al., 2010; Tiwari et al., 2016), which becomes important in $\mathrm{PM}_{2.5-10}$. Higher concentrations of chloride in fine particles (964 and $330 \mathrm{ng} \mathrm{m}^{-3}$ for $\mathrm{Int}_{2.5}$ and $\mathrm{Ext}_{2.5}$, respectively) were observed in the Int 2.5 campaign (although the value of $p$ was slightly above 0.05 ), probably due to a higher influence of biomass burning (Allen et al., 2004). Conversely, chloride in coarse particles is mostly attributed to marine aerosols. $\mathrm{Cl}^{-} / \mathrm{Na}^{+}$ratios were below 1.8 in $\mathrm{Ext}_{2.5}$ and $\mathrm{Ext}_{10}$ and higher in $\mathrm{Int}_{2.5}$; although $\mathrm{Cl}^{-} / \mathrm{Na}^{+}$ ratios are attributed to increased sea salt contribution (Souza et al., 2014a), the higher contribution in the intensive campaign may be explained by a higher contribution of other sources of chloride, such as biomass burning, in that period.

Pearson correlations were obtained for all determined species in Ext 2.5 and Ext $2.5-10$ (coarse mode), including meteorological data such as temperature, relative humidity and wind speed. Some gaseous species such as $\mathrm{NO}_{x}$ and $\mathrm{CO}$ were obtained from the CETESB database and were also included. $\mathrm{NO}_{x}$ was monitored at a station inside the university campus (IPEN, $800 \mathrm{~m}$ away from the sampling site, at ground level) and $\mathrm{CO}$ was monitored at another station (Pinheiros, 
Table 4. Average, minimum and maximum concentrations of tracer elements for all campaigns.

\begin{tabular}{lrrr}
\hline & Int $_{2.5}$ & Ext $_{2.5}$ & Ext $_{10}$ \\
\cline { 2 - 4 }$\left(\mathrm{ng} \mathrm{m}^{-3}\right)$ & Average $($ min-max $)$ & Average $($ min-max $)$ & Average $($ min-max $)$ \\
\hline $\mathrm{Li}$ & $0.48(<\mathrm{DL}-1.12)$ & $0.27(<\mathrm{DL}-0.70)$ & $0.40(<\mathrm{DL}-1.25)$ \\
$\mathrm{Mg}$ & $210(5-469)$ & $93(5-356)$ & $154(<\mathrm{DL}-377)$ \\
$\mathrm{Al}$ & $1851(<\mathrm{DL}-2782)$ & $691(<\mathrm{DL}-2712)$ & $981(<\mathrm{DL}-3014)$ \\
$\mathrm{K}$ & $1431(191-3833)$ & $500(<\mathrm{DL}-1967)$ & $600(<\mathrm{DL}-1682)$ \\
$\mathrm{Ca}$ & $1164(<\mathrm{DL}-3204)$ & $397(<\mathrm{DL}-1671)$ & $666(<\mathrm{DL}-2160)$ \\
$\mathrm{Cr}$ & $23(1-60)$ & $13(1-60)$ & $20(<\mathrm{DL}-54)$ \\
$\mathrm{Mn}$ & $30(<\mathrm{DL}-64)$ & $17(<\mathrm{DL}-49)$ & $33(4-175)$ \\
$\mathrm{Fe}$ & $962(173-2056)$ & $581(140-1408)$ & $1269(240-3578)$ \\
$\mathrm{Co}$ & $0.45(0.03-1.06)$ & $0.23(0.01-0.78)$ & $0.59(0.07-1.74)$ \\
$\mathrm{Ni}$ & $7.3(2.3-14.8)$ & $4.6(<\mathrm{DL}-16.1)$ & $6.6(<\mathrm{DL}-25.9)$ \\
$\mathrm{Cu}$ & $181(7-390)$ & $109(7-308)$ & $188(32-976)$ \\
$\mathrm{Zn}$ & $284(<\mathrm{DL}-673)$ & $110(<\mathrm{DL}-279)$ & $193(<\mathrm{DL}-716)$ \\
$\mathrm{As}$ & $2.8(0.06-5.7)$ & $1.9(<\mathrm{DL}-7.1)$ & $2.2(<\mathrm{DL}-7.9)$ \\
$\mathrm{Se}$ & $5.6(<\mathrm{DL}-13.2)$ & $2.6(<\mathrm{DL}-7.5)$ & $2.6(<\mathrm{DL}-7.9)$ \\
$\mathrm{Rb}$ & $5.7(0.4-12.3)$ & $2.2(0.1-8.9)$ & $2.6(0.2-8.9)$ \\
$\mathrm{Sr}$ & $6.6(0.4-13.4)$ & $3.0(0.2-12.2)$ & $4.8(0.4-14.3)$ \\
$\mathrm{Cd}$ & $2.5(0.2-15.1)$ & $0.8(0.1-3.0)$ & $1.2(0.2-10.6)$ \\
$\mathrm{Sn}$ & $19.5(3.2-40.2)$ & $8.8(0.3-35.9)$ & $12.3(1.6-41.8)$ \\
$\mathrm{Cs}$ & $0.28(0.07-1.01)$ & $0.14(<\mathrm{DL}-0.51)$ & $0.19(0.02-0.77)$ \\
$\mathrm{Tl}$ & $0.21(<\mathrm{DL}-0.75)$ & $0.13(<\mathrm{DL}-0.38)$ & $0.15(0.03-0.65)$ \\
$\mathrm{Pb}$ & $54(3-172)$ & $31(3-71)$ & $42(4-176)$ \\
$\mathrm{Bi}$ & $0.76(0.06-3.03)$ & $0.47(<\mathrm{DL}-3.03)$ & $0.83(0.12-3.24)$ \\
\hline & & &
\end{tabular}

$<$ DL: below detection limit.

$3.2 \mathrm{~km}$ away, at $2 \mathrm{~m}$ height). Previous studies have identified high correlations of pollutant concentrations between the IPEN station and the sampling site (Oyama et al., 2016; Vara-Vela et al., 2016). $\mathrm{NH}_{4}^{+}$was moderately to strongly correlated with $\mathrm{C}_{2} \mathrm{O}_{4}^{2-}$ (oxalate), $\mathrm{Cl}^{-}, \mathrm{NO}_{3}^{-}$and $\mathrm{SO}_{4}^{2-}$ in $\operatorname{Ext}_{2.5}(R=0.66,0.62,0.85$ and 0.79 , respectively), suggesting the neutralization of oxalic, hydrochloric, nitric and sulfuric acids by $\mathrm{NH}_{3}$ (Table $\mathrm{S} 2$ ). The formation of $\left(\mathrm{NH}_{4}\right)_{2} \mathrm{SO}_{4}$, a nonvolatile species, could represent a gas-to-particle conversion process and can account for the formation of new particles through nucleation (Mkoma et al., 2014; da Rocha et al., 2005) and can lead to $\mathrm{CCN}$ formation. $\mathrm{NH}_{4} \mathrm{NO}_{3}$ and $\mathrm{NH}_{4} \mathrm{Cl}$ also have an important influence on Earth's acid deposition (Tang et al., 2016).

$\mathrm{Na}^{+}$was strongly correlated with $\mathrm{Cl}^{-}$in $\operatorname{Ext}_{2.5}(R=0.78)$ and presented a relatively moderate correlation $(R=0.35)$ in $E_{2 x} t_{2-5}$-10. These species are often associated with marine aerosol, which is mainly in the coarse mode (Godoy et al., 2009; da Rocha et al., 2012). Although it was observed that ocean influence is not the only source of $\mathrm{Na}^{+}$at the site, this species may have vehicular sources (Vieira-Filho et al., 2016). $\mathrm{C}_{2} \mathrm{O}_{4}^{2-}$ was also moderately correlated with $\mathrm{NO}_{3}^{-}, \mathrm{SO}_{4}^{2-}$ and $\mathrm{K}^{+}(R=0.67,0.61$ and 0.68 , respectively $)$. These species-reported sources can be biomass burning and secondary conversion of natural and anthropogenic gases (Custódio et al., 2016). The secondarily formed species were negatively correlated with wind speed (from $R=-0.40$ to $R=-0.70$ ); lower wind speed can increase in the formation of secondary ionic species due to an increase in the precursor species concentrations (Yu et al., 2017).

Average, maximum and minimum trace element concentrations are presented in Table $4 . \mathrm{Mg}, \mathrm{Al}, \mathrm{K}, \mathrm{Ca}, \mathrm{Fe}, \mathrm{Cu}$ and $\mathrm{Zn}$ were the most abundant elements in all campaigns, similar to those observed by Vasconcellos et al. (2011a) for the intensive campaign in 2008. All of them had higher concentrations in $\mathrm{Int}_{2.5}$ than in $\mathrm{Ext}_{2.5}$. However, crustal elements were significantly higher; $\mathrm{Al}$ and $\mathrm{Ca}$ had concentrations nearly 3 times higher in the intensive campaign $(p<0.05)$. A similar trend was observed between wintertime and summertime campaigns by Castanho and Artaxo (2001). They reported higher concentrations of soil resuspension elements during wintertime. An increase in soil resuspension is expected in drier conditions.

As observed for $\mathrm{nss}-\mathrm{K}^{+}$, elemental $\mathrm{K}$ average concentration was more than twice as high in $\mathrm{Int}_{2.5}$ than in $\mathrm{Ext}_{2.5}$ $(p<0.05)$. This may be explained by a higher biomass burning contribution during the intensive campaign since sugarcane burning significantly increases in this time of the year. $\mathrm{Cu}$ has been attributed to vehicular emissions in São Paulo (Castanho and Artaxo, 2001) because it may be present in the ethanol, which is mixed with gasoline and used in lightduty vehicles (LDVs) in Brazil. $\mathrm{Cu}$ has also been related to 
wear emissions of road traffic (Pio et al., 2013). This element was approximately $70 \%$ higher in Int $_{2.5}$ than $\mathrm{Ext}_{2.5}$. Although there is no significant difference in vehicular emissions all year round, the meteorological conditions are more unfavorable to pollutant dispersion in the winter season.

The enrichment factor $(\mathrm{EF})$ is an approximation often used in order to identify the degree to which an element in an aerosol is enriched or depleted regarding a specific source. EFs are calculated based on a reference metal (Al as a soil tracer in this study), considering crustal element composition (Lee, 1999). A convention often adopted is to consider that when elements have EFs below 10 they have significant crustal sources and are often called non-enriched elements (NEEs), and when the elements have EFs above 10 they have a higher non-crustal character and are referred to as anomalously enriched elements (AEEs) (Pereira et al., 2007). Values were higher than 10 for $\mathrm{Cr}$ (except for $\mathrm{Int}_{2.5}$ ), $\mathrm{Cu}, \mathrm{Zn}, \mathrm{As}$, $\mathrm{Se}, \mathrm{Cd}, \mathrm{Sn}, \mathrm{Tl}, \mathrm{Pb}$ and $\mathrm{Bi}$, meaning that they can be attributed to anthropogenic sources as vehicular and industry emissions (Table S3). Elements like K, Mn, Ni, Rb, Sr, Cs, Li, Mg, Ca, $\mathrm{Fe}, \mathrm{Co}$ and $\mathrm{Sr}$ had EFs lower than 10 and could be attributed to soil resuspension (da Rocha et al., 2012).

Strong correlations were observed between $\mathrm{Al}$ and $\mathrm{Li}$, $\mathrm{Mg}, \mathrm{K}, \mathrm{Ca}, \mathrm{Mn}, \mathrm{Fe}, \mathrm{Rb}$ and $\mathrm{Sr}(R>0.85)$ in $\mathrm{Ext}_{2.5} . \mathrm{Al}$ also had strong correlations with $\mathrm{Li}, \mathrm{Mg}, \mathrm{K}, \mathrm{Ca}$ and $\mathrm{Fe}$ in $\mathrm{Ext}_{2.5-10}(R>0.70)$. Strong correlations were observed between species like $\mathrm{Cl}^{-}$and $\mathrm{NO}_{3}^{-}$and $\mathrm{Mg}, \mathrm{Al}, \mathrm{Ca}$ and $\mathrm{Fe}$ $(R>0.7)$; atmospheric reactions can occur between acids $\left(\mathrm{HCl}\right.$ and $\left.\mathrm{HNO}_{3}\right)$ and soil particles that have alkaline character (Rao et al., 2016). Mg, Al, K, Sr and Fe were negatively correlated with relative humidity $(R \leq-0.60)$, suggesting a strong influence of drier conditions over these species.

\subsection{OC, EC and mass balance}

Higher concentrations of OC and EC were observed in $\mathrm{Int}_{2.5}$ than in $\mathrm{Ext}_{2.5}$, with average values of $10.2 \mu \mathrm{g} \mathrm{m}^{-3}$ for OC and $7.0 \mu \mathrm{g} \mathrm{m}^{-3}$ for EC (Fig. 4 and Table S4). However, the difference in carbonaceous species concentrations was not considered statistically significant between the campaigns ( $p \sim 0.1)$. The OC / EC ratios were 1.5, 1.7 and 1.8 for Int $_{2.5}$, Ext $_{2.5}$ and $\mathrm{Ext}_{10}$, respectively. Since the ratio values were similar, and the absolute OC and EC concentrations were higher in intensive than extensive campaigns, this may indicate that similar sources of OC and EC contribute all year long but with higher concentrations during Int 2.5 . Ratios lower than 1 are constantly observed in roadway tunnels and are assumed to describe the composition of fresh traffic emissions (Pio et al., 2011). Amato et al. (2016) found values ranging from 1.8 to 3.7 at the urban background sites using equivalent measurement protocols. It was attributed to the distance from main roads, which can increase the influence of secondary OC (Pio et al., 2011). In this way, the values for OC / EC found in the present study may be due to

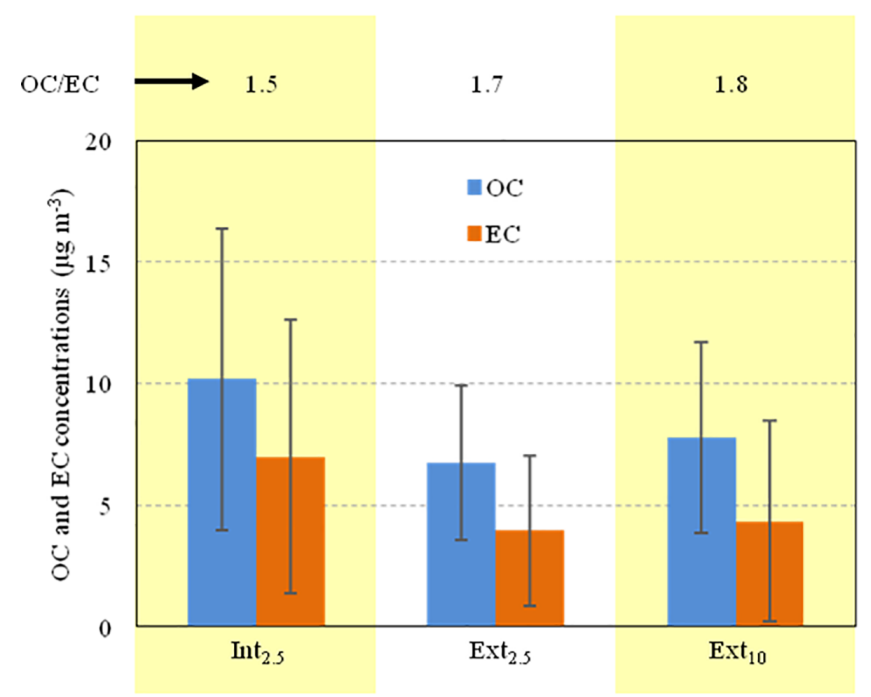

Figure 4. Carbonaceous species concentrations for all campaigns.

vehicle emissions with contributions from secondary organic aerosols.

TOM (total organic matter) was calculated by multiplying the OC content by 1.6 (Timonen et al., 2013) and represented 36,36 and $28 \%$ of the total PM (Fig. S2). Mass balance was determined for the aerosol by considering trace elements as if they all existed as oxides (Alves et al., 2015). The unaccounted part was 6, 15 and $26 \%$ for Int $_{2.5}$, Ext $_{2.5}$ and Ext 10 , respectively. This unaccounted part can be attributed to adsorbed water or the fact that abundant species as carbonates and $\mathrm{Si}$ were not determined, as similarly observed in Pio et al. (2013).

$\mathrm{OC}$ and $\mathrm{EC}$ were well correlated in $\mathrm{Ext}_{2.5}$, with values above 0.8 . This suggests that a large amount of $\mathrm{OC}$ is emitted by a dominant primary source at this site (Aurela et al., 2011; Kumar and Attri, 2016). The studied site is strongly affected by vehicle emissions and during the winter months biomass burning also contributes to these species (Pereira et al., 2017). Correlations were strong between the carbonaceous species with vehicular-emitted gases such as $\mathrm{NO}_{x}$ and $\mathrm{CO}(R>0.85)$. OC also had good correlations with soil elements $(\mathrm{Mg}$ and $\mathrm{Al})$ and also nss- $\mathrm{K}^{+}(R>0.8)$, suggesting an association with the resuspension of road dust and also a significant biomass burning contribution.

\subsection{Polycyclic aromatic hydrocarbons and derivatives}

The PAH and derivative concentrations are presented in Table 5. The total PAHs were higher in $\mathrm{Int}_{2.5}$ than in $\mathrm{Ext}_{2.5}$; 23.3 and $18.4 \mathrm{ng} \mathrm{m}^{-3}$, respectively (although not significantly different, with $p>0.05$ ). The total PAH concentration for the Ext 10 was $24.3 \mathrm{ng} \mathrm{m}^{-3}$. The lowest total PAH concentration of $2.6 \mathrm{ng} \mathrm{m}^{-3}$ was observed in Ext 2.5 , while the maximum of $115.3 \mathrm{ng} \mathrm{m}^{-3}$ was observed in $\operatorname{Ext}_{10}$. These levels were similar to those obtained in past studies at the same 
Table 5. Concentrations of PAHs and derivatives for all campaigns.

\begin{tabular}{|c|c|c|c|}
\hline \multirow[b]{2}{*}{$\left(\mathrm{ng} \mathrm{m}^{-3}\right)$} & $\mathrm{Int}_{2.5}$ & $\mathrm{Ext}_{2.5}$ & \multirow{2}{*}{$\begin{array}{r}\text { Ext }_{10} \\
\text { Average (min-max) }\end{array}$} \\
\hline & Average (min-max) & Average (min-max) & \\
\hline Nap & $0.30(0.17-0.77)$ & $0.36(0.02-0.77)$ & $0.41(0.09-0.81)$ \\
\hline Acy & $0.09(0.06-0.12)$ & $0.10(0.03-0.19)$ & $0.12(0.05-0.34)$ \\
\hline Ace & $0.03(0.02-0.08)$ & $0.05(0.02-0.16)$ & $0.07(0.02-0.23)$ \\
\hline Flu & $0.27(0.15-1.03)$ & $0.31(0.06-1.44)$ & $0.51(0.10-1.75)$ \\
\hline Phe & $0.65(0.30-2.48)$ & $0.74(0.12-3.55)$ & $1.28(0.28-4.08)$ \\
\hline Ant & $0.17(0.10-0.44)$ & $0.16(0.06-0.60)$ & $0.25(0.08-0.67)$ \\
\hline Flt & $0.48(0.21-0.86)$ & $0.53(0.06-1.40)$ & $0.73(0.19-2.21)$ \\
\hline Pyr & $0.52(0.20-0.99)$ & $0.54(0.07-1.54)$ & $0.71(0.19-2.45)$ \\
\hline $\mathrm{BaA}$ & $1.0(0.3-2.4)$ & $0.9(0.1-4.8)$ & $1.2(0.3-5.9)$ \\
\hline $\mathrm{Chr}$ & $1.8(0.5-4.4)$ & $1.6(0.3-5.7)$ & $2.1(0.5-10.5)$ \\
\hline $\mathrm{BbF}$ & $3.0(0.9-6.1)$ & $2.3(0.5-6.4)$ & $3.0(0.7-13.3)$ \\
\hline $\mathrm{BkF}$ & $2.5(0.6-5.2)$ & $1.9(0.2-7.4)$ & $2.5(0.4-11.8)$ \\
\hline $\mathrm{BeP}$ & $2.8(0.6-6.1)$ & $2.2(0.3-7.3)$ & $2.8(0.5-14.4)$ \\
\hline $\mathrm{BaP}$ & $2.3(0.4-5.5)$ & $1.6(0.2-7.6)$ & $2.0(0.3-12.5)$ \\
\hline Per & $0.35(0.04-0.79)$ & $0.27(<\mathrm{DL}-1.27)$ & $0.38(0.05-1.90)$ \\
\hline $\mathrm{InP}$ & $2.9(0.6-6.0)$ & $1.8(0.3-6.3)$ & $2.4(0.4-13.2)$ \\
\hline DBA & $0.8(0.1-2.3)$ & $0.6(0.0-2.0)$ & $0.9(0.0-5.1)$ \\
\hline $\mathrm{BPe}$ & $2.4(0.5-4.8)$ & $1.6(0.2-5.5)$ & $2.1(0.4-10.5)$ \\
\hline Cor & $1.0(0.1-2.4)$ & $0.7(0.0-2.4)$ & $0.9(0.1-5.2)$ \\
\hline Total & $23.3(6.0-48.8)$ & $18.4(2.6-61.6)$ & $24.3(5.4-115.3)$ \\
\hline $\mathrm{BaPE}$ & $3.4(0.6-8.0)$ & $2.4(0.3-10.5)$ & $3.2(0.5-18.3)$ \\
\hline 1-NNap & $<\mathrm{DL}$ & $<\mathrm{DL}$ & $<\mathrm{DL}$ \\
\hline 1-Methyl-4-NNap & $<\mathrm{DL}$ & $<\mathrm{DL}$ & $<\mathrm{DL}$ \\
\hline 2-NNap & $<\mathrm{DL}$ & $<\mathrm{DL}$ & $<\mathrm{DL}$ \\
\hline 2-NBP & $0.56(<\mathrm{DL}-1.36)$ & $0.56(<\mathrm{DL}-1.36)$ & $1.23(0.47-2.47)$ \\
\hline 1-Methyl-5-NNap & $0.18(<\mathrm{DL}-0.28)$ & $<\mathrm{DL}$ & $<\mathrm{DL}$ \\
\hline 1-Methyl-6-NNap & $0.36(<\mathrm{DL}-0.40)$ & $0.27(<\mathrm{DL}-0.41)$ & $0.29(<\mathrm{DL}-0.86)$ \\
\hline 2-Methyl-4-NNap & $0.45(<\mathrm{DL}-0.45)$ & $0.36(<\mathrm{DL}-0.44)$ & $0.42(<\mathrm{DL}-1.26)$ \\
\hline $3-\mathrm{NBP}$ & $0.60(0.48-0.88)$ & $0.52(<\mathrm{DL}-0.87)$ & $0.55(<\mathrm{DL}-1.58)$ \\
\hline 4-NBP & $<\mathrm{DL}$ & $<\mathrm{DL}$ & $0.18(<\mathrm{DL}-0.41)$ \\
\hline 5-NAce & $<\mathrm{DL}$ & $<\mathrm{DL}$ & $0.20(<\mathrm{DL}-0.52)$ \\
\hline 2-NFlu & $0.98(0.78-1.39)$ & $0.99(0.38-1.56)$ & $1.09(0.54-1.79)$ \\
\hline 2-NPhe & $0.43(0.30-0.67)$ & $0.51(0.19-1.40)$ & $0.61(<\mathrm{DL}-1.80)$ \\
\hline 3-NPhe & $0.43(<\mathrm{DL}-0.46)$ & $0.44(<\mathrm{DL}-0.68)$ & $0.47(<\mathrm{DL}-1.11)$ \\
\hline 9-NPhe & $0.62(<\mathrm{DL}-0.64)$ & $0.52(<\mathrm{DL}-0.64)$ & $0.55(<\mathrm{DL}-0.82)$ \\
\hline 2-Nant & $0.66(<\mathrm{DL}-0.80)$ & $0.56(<\mathrm{DL}-0.80)$ & $0.61(<\mathrm{DL}-0.88)$ \\
\hline 9-Nant & $0.44(<\mathrm{DL}-0.57)$ & $0.42(<\mathrm{DL}-0.69)$ & $0.46(<\mathrm{DL}-1.15)$ \\
\hline 2-NFlt & $1.19(<\mathrm{DL}-1.35)$ & $0.98(<\mathrm{DL}-1.25)$ & $1.02(<\mathrm{DL}-1.43)$ \\
\hline 3-NFlt & $1.45(<\mathrm{DL}-1.48)$ & $1.05(<\mathrm{DL}-1.48)$ & $1.02(<\mathrm{DL}-1.11)$ \\
\hline 1-NPyr & $0.98(<$ DL -1.12$)$ & $0.73(<\mathrm{DL}-0.88)$ & $0.79(<\mathrm{DL}-1.28)$ \\
\hline 2-NPyr & $0.94(<\mathrm{DL}-0.99)$ & $0.76(<\mathrm{DL}-0.99)$ & $0.78(<\mathrm{DL}-1.27)$ \\
\hline 4-NPyr & $1.61(<\mathrm{DL}-1.67)$ & $1.27(<\mathrm{DL}-1.34)$ & $1.28(<\mathrm{DL}-1.72)$ \\
\hline 7-NBaA & $1.19(<\mathrm{DL}-1.34)$ & $0.91(<\mathrm{DL}-1.06)$ & $1.01(<\mathrm{DL}-1.67)$ \\
\hline 6-NChr & $<\mathrm{DL}$ & $0.60(<\mathrm{DL}-0.67)$ & $0.69(0.58-1.10)$ \\
\hline $3-N B A$ & $<\mathrm{DL}$ & $<\mathrm{DL}$ & $<\mathrm{DL}$ \\
\hline 6-NBaPyr & $<\mathrm{DL}$ & $<\mathrm{DL}$ & $1.01(<\mathrm{DL}-1.19)$ \\
\hline 1-NBaPyr & $<\mathrm{DL}$ & $<\mathrm{DL}$ & $<\mathrm{DL}$ \\
\hline 3NBePyr & $<\mathrm{DL}$ & $<\mathrm{DL}$ & $<\mathrm{DL}$ \\
\hline 1,4-BQ & $<\mathrm{DL}$ & $<\mathrm{DL}$ & $<\mathrm{DL}$ \\
\hline 1,4-NQ & $0.54(0.43-0.72)$ & $0.44(0.28-0.67)$ & $0.46(0.31-1.08)$ \\
\hline $1,2-\mathrm{NQ}$ & $<\mathrm{DL}$ & $<\mathrm{DL}$ & $<\mathrm{DL}$ \\
\hline $9,10-\mathrm{AQ}$ & $1.6(0.8-3.7)$ & $2.5(0.3-8.0)$ & $2.6(0.4-10.9)$ \\
\hline 9,10-PQ & $<\mathrm{DL}$ & $<\mathrm{DL}$ & $<\mathrm{DL}$ \\
\hline Total PAHs / OC (\%) & 0.23 & 0.27 & 0.31 \\
\hline 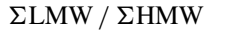 & 0.32 & 0.41 & 0.43 \\
\hline Flt / (Flt + Pyr) & 0.5 & 0.5 & 0.5 \\
\hline $\mathrm{BaA} / \mathrm{Chr}$ & 0.5 & 0.6 & 0.5 \\
\hline $\mathrm{InP} /(\mathrm{InP}+\mathrm{BPe})$ & 0.5 & 0.5 & 0.5 \\
\hline $\mathrm{BaP} /(\mathrm{BaP}+\mathrm{BeP})$ & 0.4 & 0.4 & 0.4 \\
\hline $\mathrm{BPe} / \mathrm{BaP}$ & 1 & 1 & 1 \\
\hline 2-NFlt / 1-NPyr & 1.3 & 1.3 & 1.3 \\
\hline
\end{tabular}


site, as $25.9 \mathrm{ng} \mathrm{m}^{-3}$ in $\mathrm{PM}_{10}$ samples during the intensive campaign in the winter of 2008 (Vasconcellos et al., 2011a) and $27.4 \mathrm{ng} \mathrm{m}^{-3}$ for $\mathrm{PM}_{10}$ in the winter of 2003 (Vasconcellos et al., 2011b). In addition, the total PAH levels from the present study are higher than in the 2013 and 2012 intensive campaigns (8.7 and $8.2 \mathrm{ng} \mathrm{m}^{-3}$ in $\mathrm{PM}_{10}$ ) (Pereira et al., 2017). Total PAHs represented $0.23,0.27$ and $0.31 \%$ of OC for $\mathrm{Int}_{2.5}, \mathrm{Ext}_{2.5}$ and $\mathrm{Ext}_{10}$, respectively. In spite of accounting for a small fraction of $\mathrm{OC}$, it is important to observe that PAHs are among the pollutants of major concern due to their carcinogenic and mutagenic effects.

$\mathrm{BbF}$ was the most abundant $\mathrm{PAH}$ (the $\mathrm{BbF}$ percentages in relation to total PAHs were 13, 12 and $12 \%$ for $\mathrm{Int}_{2.5}, \mathrm{Ext}_{2.5}$ and $\mathrm{Ext}_{10}$, respectively) in all the campaigns. This compound has carcinogenic properties already reported in other studies (Ravindra et al., 2008). Its concentrations reached the values of 6.1, 6.4 and $13.3 \mathrm{ng} \mathrm{m}^{-3}$ in $\mathrm{Int}_{2.5}, \mathrm{Ext}_{2.5}$ and $\mathrm{Ext}_{10}$, respectively. $\mathrm{BbF}$ was also the most abundant $\mathrm{PAH}$ in the 2013 intensive campaign (Pereira et al., 2017). This species was also among the most abundant PAHs in the study performed at the Jânio Quadros (JQ) tunnel, with a predominance of LDVs (Brito et al., 2013). Correlations were strong between all PAHs heavier than Flt $(R>0.8)$, suggesting different sources of the PAHs with lower molecular weight at this site. Most of the heavier PAHs appeared to have negative correlations with temperature; the condensation of organic compounds in the aerosol is influenced by lower temperatures (Bandowe et al., 2014). Coronene, a PAH often used as a vehicular fuel marker (Ravindra et al., 2006) was correlated to vehicular-related species as $\mathrm{Cu}$ and $\mathrm{Pb}(R>0.7)$.

$\mathrm{BaP}$, the PAH most studied due to its proven carcinogenic potential, was considerably higher in $\mathrm{Int}_{2.5}$ than in $\mathrm{Ext}_{2.5}$. It reached the mean values of $5.5,7.6$ and $12.5 \mathrm{ng} \mathrm{m}^{-3}$ in $\mathrm{Int}_{2.5}$, $\mathrm{Ext}_{2.5}$ and $\mathrm{Ext}_{10}$, respectively. In the tunnels, its presence was associated with the higher contribution of LDV emissions (Brito et al., 2013). Among the nitro-PAHs with highest concentrations were 2-NFlu and 2-NBP. The nitro-PAH 2NFlu is a major component of diesel exhaust particles, such as the nitropyrenes, and is known as a carcinogenic nitroPAH (Draper, 1986; Fujimoto et al., 2003). The PAH 2-NFlt was moderately correlated with Flt $(R=0.4)$; this species is produced from reactions between Flt and $\mathrm{NO}_{2}$ (Albinet et al., 2008). The 2-NFlt / 1-NPyr ratios were close to 1; ratios lower than 5 indicate a predominance of primary emissions of nitro-PAHs (Ringuet et al., 2012). The compound 9,10-AQ was the most abundant oxy-PAH found in this study. It can be either primarily emitted or secondarily formed. A recent study showed that it can be formed from the heterogeneous reaction between $\mathrm{NO}_{2}$ and Ant adsorbed on $\mathrm{NaCl}$ particles (sea salt) (Chen and Zhu, 2014). A moderate correlation was found between 9,10-AQ and Ant $(R=0.54)$.

\subsubsection{PAH diagnostic ratios}

The PAH diagnostic ratios (Table 5) were obtained for all the campaigns since they can point to some emission sources, such as oil products, fossil fuels, coal or biomass combustion. However, these ratios should be used with caution due to the peculiarity of fuel compositions in Brazil's car fleet. The values of PAH ratios can also be affected by changes in phase, transport and degradation (Tobiszewski and Namieœnik, 2012). The ratio of $\mathrm{BaP} /(\mathrm{BaP}+\mathrm{BeP})$ is related to the aerosol photolysis. Most of the local PAH emissions contain equal concentrations of BeP and BaP. However, $\mathrm{BaP}$ is more likely to undergo photolysis or oxidation (Oliveira et al., 2011). The average $\mathrm{BaP} /(\mathrm{BaP}+\mathrm{BeP})$ ratio was close to 0.4 for the three campaigns. This ratio was slightly lower than the ratio obtained in the 2013 intensive campaign, although still very close to 0.5 (Pereira et al., 2017); it is suggested that the PAHs found at the site are mostly emitted locally.

The Flt / (Flt + Pyr) and InP / $(\mathrm{InP}+\mathrm{BPe})$ ratios were reported to be the most conservative by Tobiszewski and Namieœnik (2012). The Flt / Flt + Pyr) ratios for all the campaigns were close to 0.5 , falling within the range for fossil fuel combustion (0.4-0.5) (de la Torre-Roche et al., 2009). The $\mathrm{InP} /(\mathrm{InP}+\mathrm{BPe})$ ratios represented values close to 0.5 , similar to the ratio obtained for the JQ tunnel (0.55) impacted by LDVs (the ratio found for the Maria Maluf (MM) tunnel was 0.36). The average $\mathrm{BaA} / \mathrm{Chr}$ ratio ranged between 0.5 and 0.6 in the 2014 campaigns, also approaching that of the JQ tunnel (0.48) (Brito et al., 2013), whilst a value of 0.79 was obtained for the MM tunnel. The $\mathrm{BaA} /(\mathrm{BaA}+\mathrm{Chr})$ ratio was reported to be sensitive to photodegradation (Tobiszewski and Namieœnik, 2012). However, it is possible to consider that this degradation was not significant due to proximity to the emission sources (the expressway). All ratios suggested a greater contribution of LDVs to PAHs at the sampling site.

The $\Sigma$ LMW / $\Sigma$ HMW ratios (PAHs with a low molecular weight (LMW) had three and four aromatic rings and PAHs with a high molecular weight (HMW) had more than four rings) were considerably low in all campaigns (predominance of HMW PAHs). It is known that LMW PAHs have higher concentrations in the gas phase while HMW PAHs are preferentially present in PM (Agudelo-Castañeda and Teixeira, 2014; Duan et al., 2007). The HMW PAH contribution was higher in winter, just as the ratios were lower, corroborating the results of some previous studies (Chen et al., 2016; Teixeira et al., 2013). In turn, HMW PAHs are more likely to be retained in particles due to their lower vapor pressure than LMW PAHs. LMW PAHs are also mostly associated with diesel engines, while HMW PAHs are predominantly emitted by gasoline exhaust (Chen et al., 2013; Cui et al., 2016; Miguel et al., 1998). The ratio between BPe and BaP for all campaigns (all close to 1) was very similar to that found in a study with Brazilian diesel LDV exhaust (1.13) (de Abrantes 
et al., 2004) and was also found in a campaign performed in São Paulo (1.11) (de Martinis et al., 2002). This may be a characteristic fingerprint for local vehicular emissions.

\subsubsection{PAH risk assessment}

$\mathrm{BaPE}$ is a parameter introduced to quantify the aerosol carcinogenicity related to all carcinogenic PAHs instead of $\mathrm{BaP}$ solely. BaPE values above $1.0 \mathrm{ng} \mathrm{m}^{-3}$ represent an increased cancer risk. The carcinogenic nitro-PAHs (1-NPyr, 4-NPyr and 6-NChr) were below the detection limit in most parts of the extensive campaign samples; thus, they were not considered in the risk assessment. BaPE is calculated according to Eq. (5), given by Yassaa et al. (2001) and Vasconcellos et al. (2011a):

$$
\begin{aligned}
\mathrm{BaPE}= & ([\mathrm{BaA}] \times 0.06)+([\mathrm{BbF}] \times 0.07)+([\mathrm{BkF}] \times 0.07) \\
& +([\mathrm{BaP}] \times 1)+([\mathrm{DBA}] \times 0.6) \\
& +([\mathrm{InP}] \times 0.08) .
\end{aligned}
$$

The BaPE values for the $\mathrm{Int}_{2.5}$ ranged between 0.6 and $8.0 \mathrm{ng} \mathrm{m}^{-3}$ and for $\mathrm{Ext}_{2.5}$ between 0.3 and $10.5 \mathrm{ng} \mathrm{m}^{-3}$, while the average of BaPE for the Int $_{2.5}$ was considerably higher than in $\operatorname{Ext}_{2.5}$ (3.4 and $2.4 \mathrm{ng} \mathrm{m}^{-3}$, respectively). In the Ext $_{10}$ this index ranged between 0.5 and $18.3 \mathrm{ng} \mathrm{m}^{-3}$. The maximum value was even higher than the value of $12.1 \mathrm{ng} \mathrm{m}^{-3}$ in $\mathrm{PM}_{10}$, obtained in São Paulo in an intensive campaign conducted in 2008 (Vasconcellos et al., 2011a). More than $70 \%$ of the samples in the Ext 10 had BaPE indexes higher than $1 \mathrm{ng} \mathrm{m}^{-3}$. The year 2014 was a relatively dry year, with an annual rainfall $13 \%$ below the average (IAG, 2014). The average values for $\mathrm{BaPE}$ in $\mathrm{PM}_{10}$ at the site were 1.9 and $3.7 \mathrm{ng} \mathrm{m}^{-3}$ in the intensive campaigns of 2007 and 2008, respectively. Conversely, at forested areas in São Paulo state the value can be as low as $0.1 \mathrm{ng} \mathrm{m}^{-3}$ (Vasconcellos et al., 2010).

The lifetime LCR was assessed from the carcinogenic potential (BaP-TEQ) and mutagenic potential (BaP-MEQ) through Eqs. (6) and (7) (Jung et al., 2010):

$$
\begin{aligned}
(\mathrm{BaP}-\mathrm{TEQ})= & ([\mathrm{BaA}] \times 0.1)+([\mathrm{Chr}] \times 0.01) \\
& +([\mathrm{BbF}] \times 0.1)+([\mathrm{BkF}] \times 0.1) \\
& +([\mathrm{BaP}] \times 1)+([\mathrm{InP}] \times 0.1) \\
& +([\mathrm{DBA}] \times 5)+([\mathrm{BPe}] \times 0.01) \\
(\mathrm{BaP}-\mathrm{MEQ})= & ([\mathrm{BaA}] \times 0.082)+([\mathrm{Chr}] \times 0.017) \\
& +([\mathrm{BbF}] \times 0.25)+([\mathrm{BkF}] \times 0.11) \\
& +([\mathrm{BaP}] \times 1)+([\mathrm{InP}] \times 0.31) \\
& +([\mathrm{DBA}] \times 0.29)+([\mathrm{BPe}] \times 0.19)
\end{aligned}
$$

DBA had the largest contribution to carcinogenic potential and $\mathrm{BaP}$ for mutagenic potential; in studies performed in urban Italian areas $\mathrm{BaP}$ was the compound that most contributed to total carcinogenicity in PM, although the

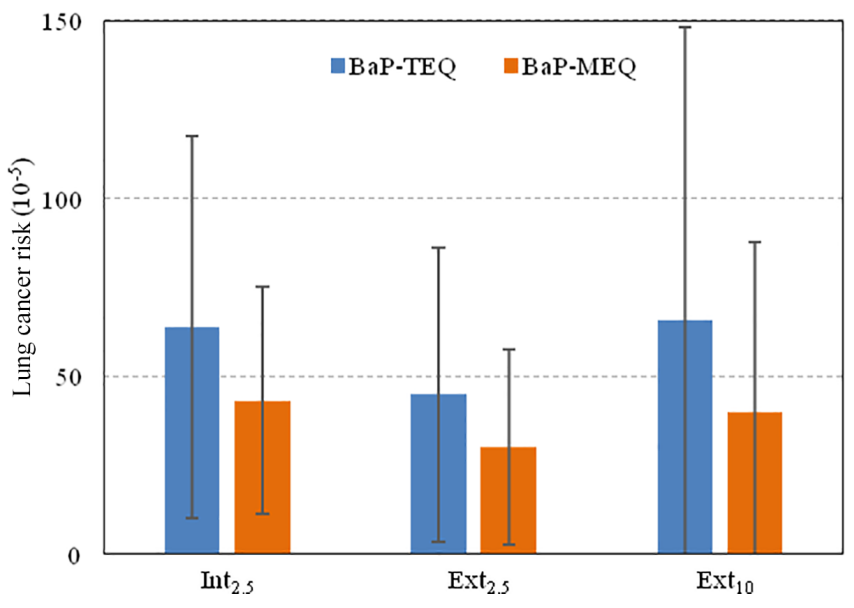

Figure 5. Lung cancer risk from the BaP-TEQ and BaP-MEQ for all three campaigns.

toxic equivalence factor (TEF) used for DBA was lower in those cases (Cincinelli et al., 2007; Gregoris et al., 2014). LCR from exposure to atmospheric PAH was estimated by multiplying BaP-TEQ and BaP-MEQ by the unit risk $\left(8.7 \times 10^{-5}\left(\mathrm{ng} \mathrm{m}^{-3}\right)^{-1}\right)$ for exposure to $\mathrm{BaP}$ established by WHO (de Oliveira Alves et al., 2015; WHO, 2000) (Fig. 5), and it was possible to observe an increase during the intensive campaign. In all campaigns, the values observed were higher than those observed in studies performed in the Amazon during the dry season with events of biomass burning (de Oliveira Alves et al., 2015); studies performed in different seasons in other urban areas such as New York and Madrid showed carcinogenic risks within the parameters recommended by environmental and health agencies (Jung et al., 2010; Mirante et al., 2013).

\subsection{Biomass burning tracers}

The highest concentrations of biomass burning tracers (mean values of 509,45 and $33 \mathrm{ng} \mathrm{m}^{-3}$ for levoglucosan, mannosan and galactosan, respectively) were observed in the Int $_{2.5}$ campaign $(p \sim 0.05)$ during the biomass burning period (Fig. 6, Table S5). In the intensive campaign period, 1364 fire spots were registered in São Paulo state, with an average of 72 fires per day (INPE, 2014). In the same way, on $65 \%$ of the sampling days the backward air masses passed through regions with biomass burning. The average concentration of levoglucosan obtained in the Int 2.5 campaign $\left(509 \mathrm{ng} \mathrm{m}^{-3}\right.$ ) was higher than that of the intensive $\mathrm{PM}_{10}$ sampling campaigns in 2013 and 2012 (474 and $331 \mathrm{ng} \mathrm{m}^{-3}$ ) (Caumo et al., 2016; Pereira et al., 2017), as well as more than twice the values obtained in the 2008 intensive campaign (Vasconcellos et al., 2010).

The Lev / Man ratios are characteristic of each type of biomass. The ratios were similar to those obtained in a chamber study with sugarcane burning $(\mathrm{Lev} / \mathrm{Man}=10)$ (Hall et 


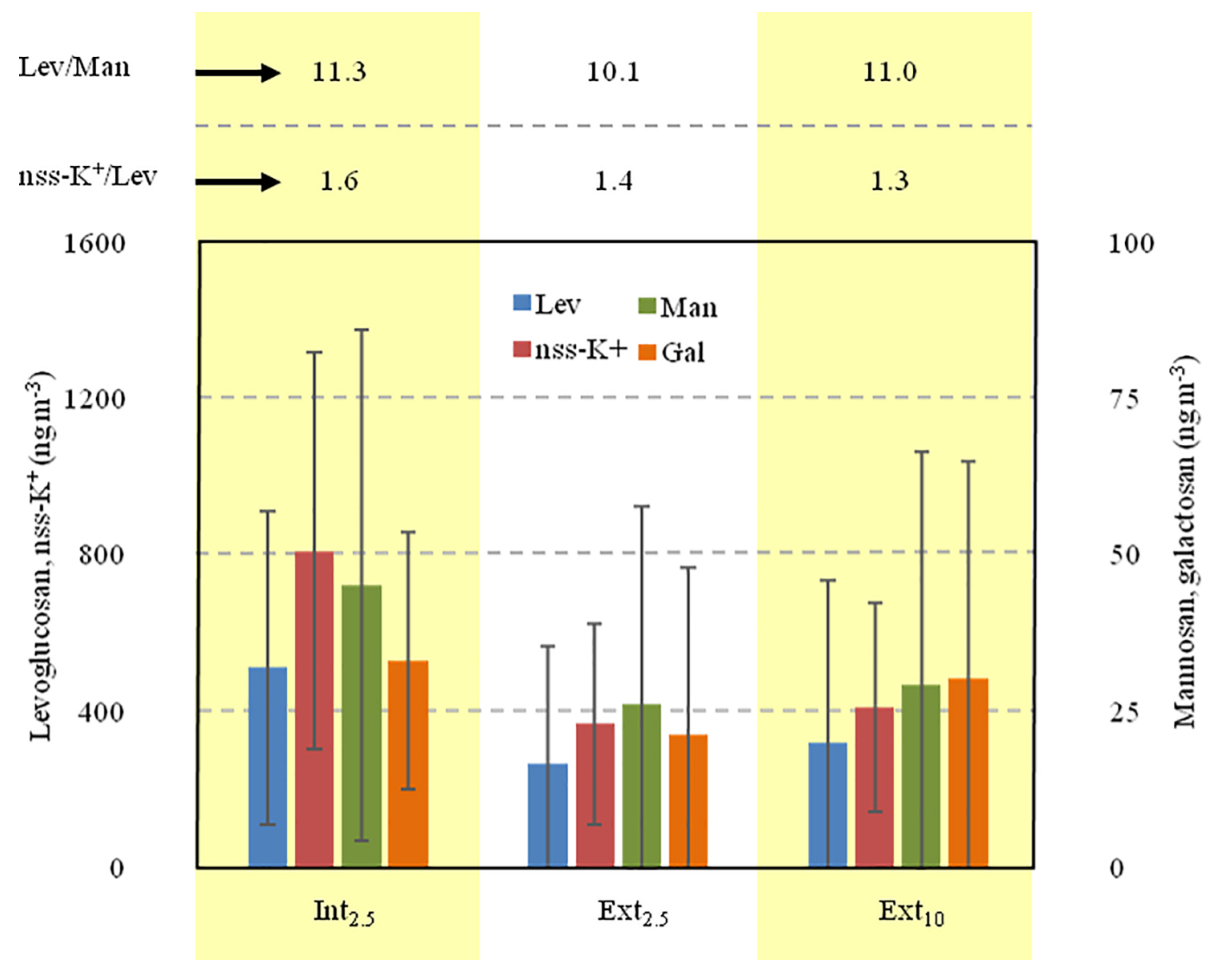

Figure 6. Concentrations of biomass burning tracers for all campaigns.

al., 2012) and also to those reported for the 2013 intensive campaign (Lev / Man =12) (Pereira et al., 2017). Nss$\mathrm{K}^{+} / \mathrm{Lev}$ ratios were 1.6, 1.4 and 1.3 for $\mathrm{Int}_{2.5}$, Ext 2.5 and Ext $_{10}$, respectively. These ratios are similar to those obtained in the previous $\mathrm{PM}_{10}$ intensive campaign (1.4) in 2013, which was attributed to a combination of smouldering (flameless combustion) and flaming processes during the combustion of biomass (Kundu et al., 2010; Pereira et al., 2017). The flaming combustion is predominant for sugarcane leaves (Hall et al., 2012; Urban et al., 2016).

Correlations between potassium and monosaccharides in $\operatorname{Ext}_{2.5}$ were high $(R>0.8)$, indicating that, most of the year, potassium in $\mathrm{PM}_{2.5}$ can be linked to biomass burning. Coarse fraction potassium, more related to soil sources, did not present strong correlations with levoglucosan. Local burning can also affect the site since some restaurants use wood for cooking (pizzerias and steakhouses) (Kumar et al., 2016). There is a stronger correlation between chloride and other biomass burning tracers in Ext 2.5 than in Ext $2.5-10$. Chloride is also a major emission from biomass burning in the form of $\mathrm{KCl}$ (Allen et al., 2004) and is also emitted as $\mathrm{HCl}$ in garbage burning (Calvo et al., 2013). Carbonaceous species presented high correlations $(R>0.75)$ with levoglucosan in $\mathrm{Ext}_{2.5}$. This suggests that some of these species may also be linked to biomass burning emissions.

The highest concentrations of biomass burning tracers were found on 1 July, when the levoglucosan level reached $1263 \mathrm{ng} \mathrm{m}^{-3}$. On that day, about 100 fire spots (INPE, 2014) were observed in the state of São Paulo and the back trajectories revealed air masses crossing the west and northwest of the state (Fig. 7a), where the fire spots were observed. On this same sampling day, local fire spots were observed, possibly due to landfill burning.

On 12 July, the air masses traveled over the Atlantic Ocean before reaching the site. In the same period, the $\mathrm{PM}_{2.5}$ and biomass burning tracer concentrations dropped. Figure $7 \mathrm{~b}$ shows the trajectories for 13 July. Some of the lowest concentrations of levoglucosan (80 and $74 \mathrm{ng} \mathrm{m}^{-3}$ ) and $\mathrm{PM}_{2.5}$ ( 28 and $26 \mu \mathrm{g} \mathrm{m}^{-3}$ ) were observed on 12 and $13 \mathrm{July}$, respectively.

\subsection{Distribution of species in fine and coarse particles during extensive campaigns}

Figure 8 shows the mass percentage of tracers in fine $\left(\mathrm{PM}_{2.5}\right)$ and coarse particles $\left(\mathrm{PM}_{2.5-10}\right)$ in the extensive campaign; their values are presented in the Supplement (Table S6). The biomass burning tracers, levoglucosan and mannosan were present mostly in $\mathrm{PM}_{2.5}$ mass fractions (over $75 \%$ ). In this study, $73 \%$ of nss- $\mathrm{K}^{+}$mass was in $\mathrm{PM}_{2.5}$. This species may also be attributed to biomass burning, although coarse potassium may be from soil dust resuspension (Souza et al., 2014a; Vasconcellos et al., 2011a).

Species related to vehicular emissions such as coronene and $\mathrm{Cu}$ (Brito et al., 2013; Ravindra et al., 2006) were also predominantly found in $\mathrm{PM}_{2.5}$ (73 and $61 \%$, respectively). 

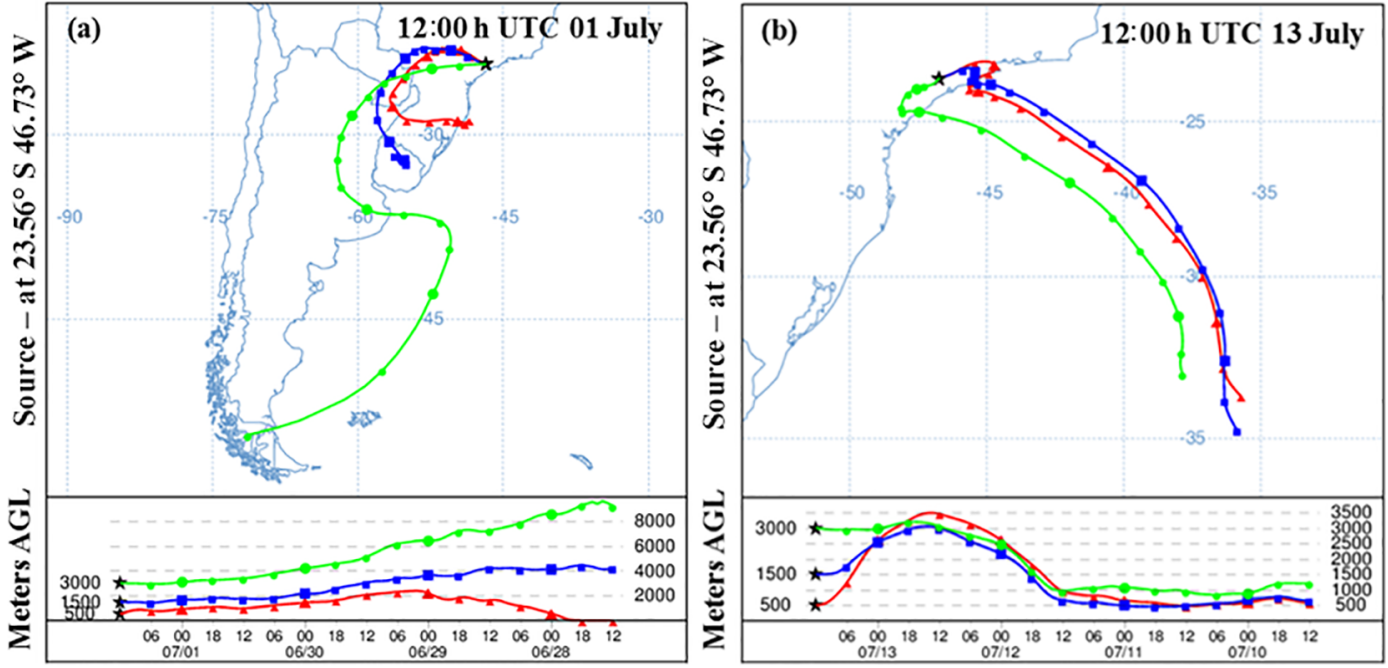

Figure 7. Backward air mass trajectories for the days (a) 1 July and (b) 13 July.

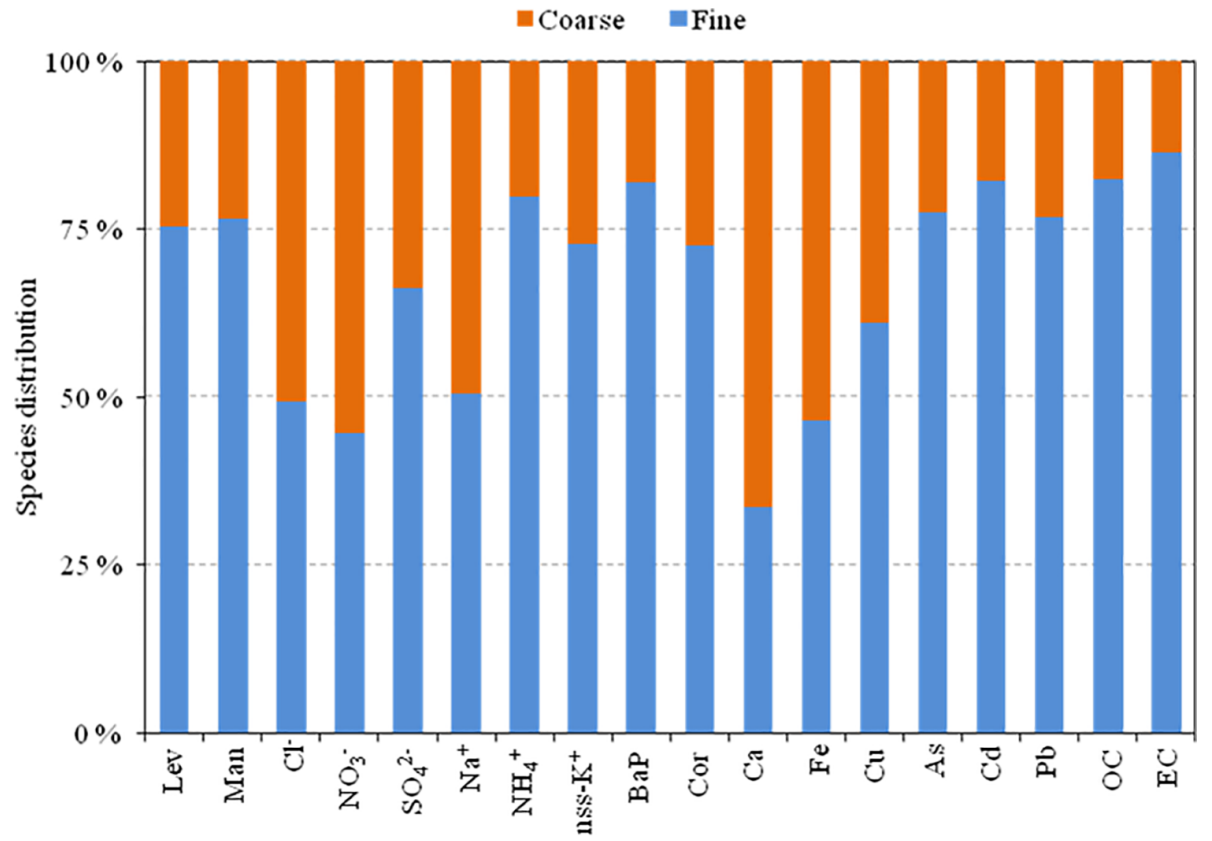

Figure 8. Mass percentage distribution of species in the fine and coarse particles.

More than $50 \%$ of $\mathrm{Fe}$ and $\mathrm{Ca}$ (crustal elements) was found in $\mathrm{PM}_{2.5-10}$. A previous source apportionment study in southern European cities (AIRUSE-LIFE+ project) also pointed out soil dust as a significant source, accounting for $2-7 \%$ of $\mathrm{PM}_{2.5}$ at suburban and urban background sites and $15 \%$ at a traffic-impacted station. In the case of $\mathrm{PM}_{10}$, these percentages increased to 7-12 and 19\%, respectively (Amato et al., 2016).

In a previous winter campaign in 2008, in São Paulo (Souza et al., 2014a) levoglucosan and mannosan were also mostly present in $\mathrm{PM}_{2.5}$. Urban et al. (2014) found that be- tween 58 and $83 \%$ of levoglucosan was present in particles smaller than $1.5 \mu \mathrm{m}$ for an agro-industrial region in São Paulo state. This is similar to the values observed in other studies done in the state of São Paulo and in the Amazon region (Decesari et al., 2006; Schkolnik et al., 2005; Urban et al., 2012).

Sulfate and ammonium were predominant in $\mathrm{PM}_{2.5}$ (over 65 and $80 \%$ ). Sulfate was also predominant in $\mathrm{PM}_{2.5}$ in a previous study done in São Paulo between 1997 and 1998; it was attributed to the gas-to-particle conversion of vehicular $\mathrm{SO}_{2}$ (Castanho and Artaxo, 2001). Both ions may be present 
as $\left(\mathrm{NH}_{4}\right)_{2} \mathrm{SO}_{4}$ in the fine mode. Nitrate is well distributed in both phases, likely resulting from reactions of $\mathrm{HNO}_{3}$ with soil species (Tang et al., 2016). In turn, fine-mode nitrate is often present in the form of ammonium nitrate, which is a thermally unstable species (Maenhaut et al., 2008).

Other ions, such as sodium and chloride were halved in each mode. These species are related to sea salt aerosols and are more often present in the coarse mode, as observed in the study done at urban sites in Rio de Janeiro (Godoy et al., 2009). Chloride in $\mathrm{PM}_{2.5}$ can also originate from biomass burning emissions (Allen et al., 2004). OC and EC, which are mainly related to vehicular emissions in São Paulo (Castanho and Artaxo, 2001), were mostly in the fine particles. OC and EC were also associated with biomass burning in a recent study (Pereira et al., 2017).

$\mathrm{BaP}$ was found mainly in the $\mathrm{PM}_{2.5}$ (over $80 \%$ ), which can be deposited in the tracheobronchial region of the human respiratory tract, representing an increased health risk (Sarigiannis et al., 2015). In turn, $\mathrm{As}, \mathrm{Cd}$ and $\mathrm{Pb}$, identified as elements that can cause carcinogenic health effects (Behera et al., 2015), were also found predominantly in the $\mathrm{PM}_{2.5}$ (over $75 \%$ ). In this way, they may be indicative of higher carcinogenicity of fine over coarse particles.

\subsection{Source apportionment using PMF and polar plots}

Source apportionment was performed with PMF including all data. Then, the factor contributions were separated for each campaign $(n=78)$. Eleven strong species were considered $\left(\mathrm{SO}_{4}^{2-}, \mathrm{nss}^{-} \mathrm{K}^{+}, \mathrm{Mg}, \mathrm{Cr}, \mathrm{Mn}, \mathrm{Fe}, \mathrm{Ni}, \mathrm{Cd}, \mathrm{Pb}, \mathrm{OC}\right.$ and $\mathrm{EC}$ ), six were considered weak (levoglucosan, mannosan, $\mathrm{NO}_{3}^{-}, \mathrm{NH}_{4}^{+}, \mathrm{Ca}$ and $\mathrm{Cu}$ ) and the $\mathrm{PM}$ concentrations were set as a total variable. An extra modeling uncertainty of $25 \%$ was added to all variables in the model. The uncertainties were increased in order to avoid discarding measurements that had poor data quality due to measurements below detection limits; this procedure was performed according to the method of Paatero and Hopke (2003). The solutions proved to be stable since the same sources could be identified in most of the solutions generated, with different additional uncertainties.

Considering the limited number of samples, a restricted number of species had to be chosen. Some variables were not considered due to high colinearity and redundancies since they would not provide more information regarding the sources. Elements already studied and attributed to sources in São Paulo were preferred. In some of the base model runs it was possible to observe a sea salt profile with $\mathrm{Na}^{+}$and $\mathrm{Cl}^{-}$, but after they were removed, other profiles were clearly improved. PAHs were first included in the model but it created a factor associated with temperature conditions, increasing in the dry season since the lower dispersion conditions in the period favor the accumulation of HMW-PAHs in suspended particles (Agudelo-Castañeda and Teixeira, 2014; Ravindra et al., 2006). Levoglucosan was set as weak since it can de- compose in the atmosphere (Pio et al., 2008), mannosan was set to weak due to concentrations below detection limit, and $\mathrm{NO}_{3}^{-}$and $\mathrm{NH}_{4}^{+}$were set to weak due to their thermal instability. $\mathrm{Ca}$ and $\mathrm{Cu}$ also had to be set as weak in order to have a convergent base model run.

Solutions with three to eight factors were tested. The ratio of robust to theoretical parameters $\left(Q_{\mathrm{R}} / Q_{\mathrm{T}}\right)$ reduced between simulations when increasing the number of factors. A solution with five factors was found to have more meaningful results; $Q_{\mathrm{R}}$ and $Q_{\mathrm{T}}$ values were 367 (Table S7). The source profiles obtained in the PMF analysis and the contribution of each factor to $\mathrm{PM}_{10}$ concentrations are found in Fig. 9. Constraints were applied, $\mathrm{Cu}$ was pulled up maximally in the vehicular factor and levoglucosan and mannosan were pulled up maximally in the biomass burning factor in order to have a better separation between both factors; relative change in $Q$ was $0.4 \%$. The PMF result charts are presented in Fig. S3.

Factor 1 presented higher loadings for $\mathrm{Mg}, \mathrm{Ca}$ and $\mathrm{Fe}$, elements associated with soil resuspension in previous studies (da Rocha et al., 2012). The factor was also mixed with vehicular-related species, such as $\mathrm{Cu}$ and $\mathrm{OC}$, which can be attributed to the resuspension of road dust by traffic. Accounting for 24.3, 12.5 and $25.7 \%$ of $\mathrm{Int}_{2.5}$, Ext 2.5 and Ext 10 , respectively, it was more relevant for the $\mathrm{PM}_{10}$ campaign. In some runs, it was possible to observe $\mathrm{Li}$ and $\mathrm{Tl}$ in this factor, but these species were not considered in the final model. This soil contribution was similar to that obtained for $\mathrm{PM}_{10}$ in a year-round inventory in the city (CETESB, 2015). High loadings for ions, such as nss- $\mathrm{K}^{+}$and $\mathrm{NO}_{3}^{-}$, were also present in the factor. Gaseous $\mathrm{HNO}_{3}$ can interact with soil particles and form coarse nitrates (Tang et al., 2016). The factor contribution appeared to increase with wind speed from the NW and decrease with SE winds (Fig. 10). Soil dust and vegetation sources also tended to reduce with SE winds, as observed previously by Sánchez-Ccoyllo and Andrade (2002).

Factor 2 shows high loads for $\mathrm{Ni}, \mathrm{Pb}$ and $\mathrm{Cr}$, which are often attributed to industrial emissions (Bourotte et al., 2011; Castanho and Artaxo, 2001). This factor had some of the lowest contributions, 10.5, 9.7, and 9.5\% for Int 2.5 , Ext 2.5 , and $\mathrm{Ext}_{10}$, and appeared to increase with SE winds, passing through nearby industrial regions (southeast of the city). The growth of industries has been limited in the last years and the vehicle fleet is expected to be a main source of atmospheric pollutants in the area (Kumar et al., 2016).

Factor 3 showed high loadings for vehicular-related tracers, such as $\mathrm{Cu}, \mathrm{Fe}, \mathrm{OC}$ and $\mathrm{EC}$ (with a higher load on EC and $\mathrm{Cu}$ ). $\mathrm{Cu}$ and $\mathrm{Fe}$ were found in the LDV-impacted tunnel study in São Paulo and $\mathrm{Cu}$ is emitted from brake pads in stopand-go driving in the expressways (Andrade et al., 2012b; Brito et al., 2013). $\mathrm{Cu}$ and $\mathrm{Fe}$ are also present in ethanol after the processing of copper tanks. Loadings for levoglucosan and mannosan were observed in this factor, which precluded the total separation from the biomass burning factor. On days with NW winds, both source contributions tended to increase as observed in the polar plots. This factor represented 30.9, 

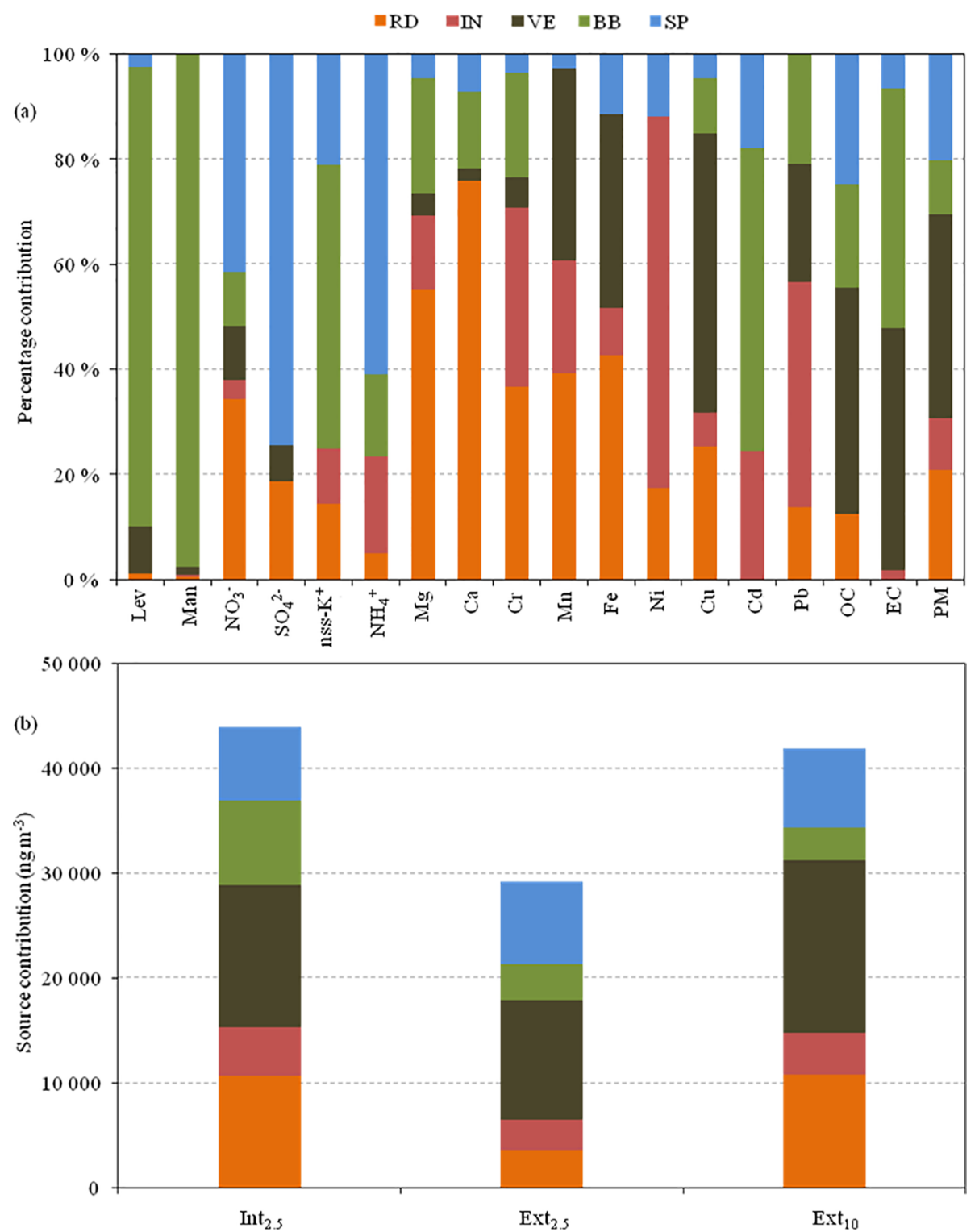

Figure 9. (a) Profile of species for each source (RD - road dust, IN - industrial, VE - vehicular, BB - biomass burning and SP - secondary processes). (b) Contribution of sources for each campaign.

39.1, and $39.2 \%$ contribution for $\operatorname{Int}_{2.5}$, Ext 2.5 , and $\operatorname{Ext}_{10}$, and had a constant contribution comparing the dry and wet periods in the $\operatorname{Ext}_{10}$ campaign. Vehicular sources seemed to increase with winds coming from the north and northwest passing by the expressway, but decreased with SE winds, as observed previously (Sánchez-Ccoyllo and Andrade, 2002). The polar plot profiles of vehicular and road dust factors presented a different pattern since the aerosol from road dust suspension has a larger aerodynamic diameter (Karanasiou et al., 2009) and tends to increase with wind speed.

Factor 4 was associated with biomass burning due to the loadings for levoglucosan, mannosan and non-sea salt potassium, OC and EC. The loading of $\mathrm{Cd}$ in this factor is also noteworthy; wood burning was pointed out as a possible source of this metal in a previous study in Belgium (Maenhaut et al., 2016), but more studies are necessary in order to explain the biomass burning contribution to this species in São Paulo. This factor represented 18.3, 11.6 and 7.6\% for $\mathrm{Int}_{2.5}, \mathrm{Ext}_{2.5}$ and $\mathrm{Ext}_{10}$, respectively. The contributions of this factor were higher in the intensive campaign (sugarcane burning period), but were also present in the other periods, suggesting other biomass burning sources in the city, such as waste burning and wood stoves (Kumar et al., 2016). Several fire spots were registered in São Paulo state in the intensive campaign, some of them in the neighboring towns (INPE, 2014). The polar plot showed that this factor tended to in- 
$\mathrm{RD}$

IN

$\mathrm{VE}$
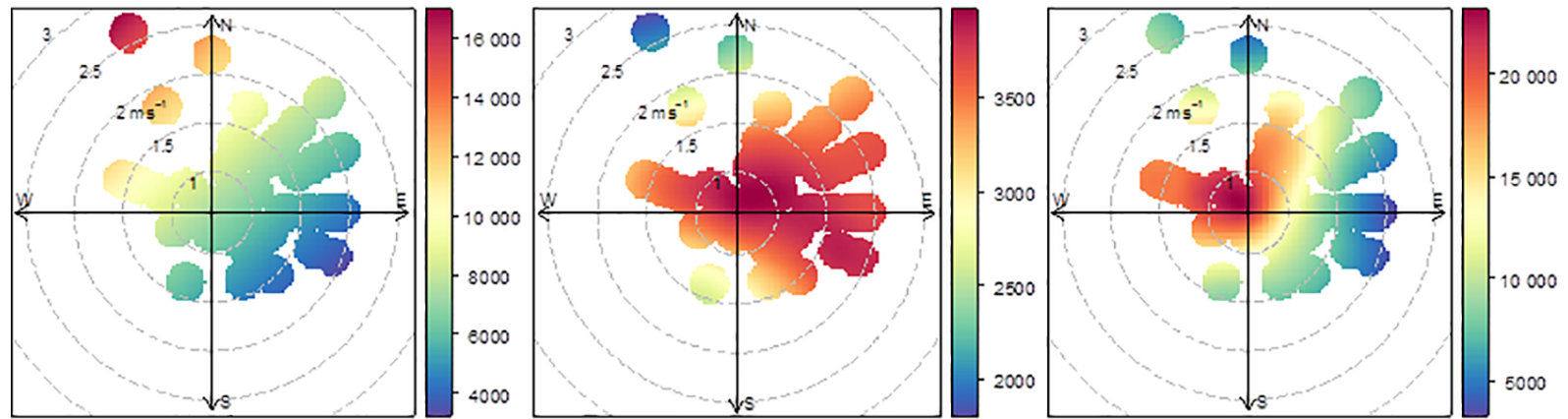

$\mathrm{BB}$

SP
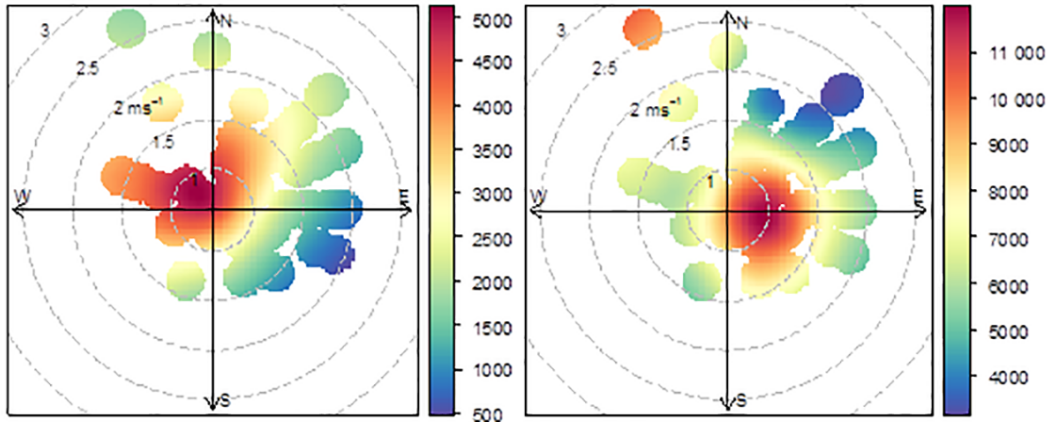

Figure 10. Polar plots of source contributions in São Paulo (ng m ${ }^{-3}$ and $\mathrm{m} \mathrm{s}^{-1}$ ).

crease with NW winds, passing through the inland of São Paulo state, and decrease with SE (more humid) winds from the sea. High correlations $(R>0.8)$ were observed between the gases $\mathrm{CO}$ and $\mathrm{NO}_{x}$ and the primary source factors vehicular and biomass burning (Table S8). These gases are related to vehicular emissions (Alonso et al., 2010) and the correlations with the biomass burning factors may be due to the fact that the biomass burning factor increases with the same wind direction as the vehicular factor. No correlations were found between these gases and secondary process factor.

Factor 5 was attributed to the secondary inorganic aerosol formation processes (as seen by high mass loadings for $\mathrm{NO}_{3}^{-}$, $\mathrm{SO}_{4}^{2-}$ and $\mathrm{NH}_{4}^{+}$) and also $\mathrm{OC}$ (secondary organic carbon). The contributions were 15.9, 27.1 and $17.9 \%$ for Int $_{2.5}$, $\mathrm{Ext}_{2.5}$ and Ext ${ }_{10}$, respectively. The contributions of this profile did not follow any seasonal trend (Fig. S3a). In 2014, $78 \%$ of $\mathrm{NO}_{x}$ and $43 \%$ of $\mathrm{SO}_{x}$ emissions in greater São Paulo were attributed to the vehicle fleet (CETESB, 2015). Taking into account that in São Paulo $\mathrm{SO}_{x}$ and $\mathrm{NO}_{x}$ concentrations are similar all year round, this could explain the lack of seasonality of this factor. The polar plot showed a centralized profile, increasing with lower wind speed, which suggests a local secondary process.

Other polar plots were obtained for individual species and are presented in Fig. 11. It is possible to see that $\mathrm{Na}^{+}$tended to increase with stronger winds coming from the sea, while $\mathrm{Cl}^{-}$had a different pattern. Chloride in the marine aerosol can be depleted after atmospheric reactions with acids (Calvo et al., 2013; White, 2008). It is noteworthy that MSA was associated with NW winds. This species is often associated with the decomposition of DMS emitted by the sea (Bardouki et al., 2003). More studies are needed in order to identify MSA sources at this site. Similarly, as for the biomass burning factor, levoglucosan tended to increase with NW winds. However, it is also possible to observe local sources for this species due to its high levels, even with lower wind speed. Secondarily formed species such as $\mathrm{NO}_{3}^{-}$and $\mathrm{SO}_{4}^{2-}$ had a centralized profile and tended to increase with lower wind speed. EC, Chr and Cor seemed to be emitted by local sources, likely vehicular emissions (Alves et al., 2016; Ravindra et al., 2008). Conversely, Flt (a light-molecularmass PAH), seemed to be influenced by different air masses, suggesting different sources.

\section{Summary and conclusions}

Particulate matter $\left(\mathrm{PM}_{2.5}\right.$ and $\left.\mathrm{PM}_{10}\right)$ was collected throughout the year 2014 to determine different chemical constituents, including carbonaceous species, WSIs, monosaccharides, PAHs and their derivatives. The risks of PAHs for human health were assessed with levels exceeding the suggested guidelines. High concentrations of biomass burning species were found in the fine particles during the campaigns. 
Lev

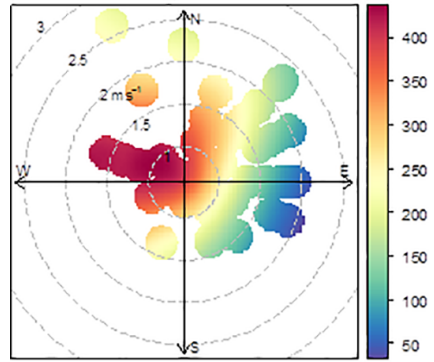

$\mathrm{SO}_{4}{ }^{2-}$

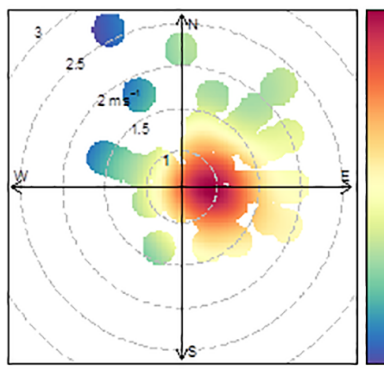

$\mathrm{Mg}$

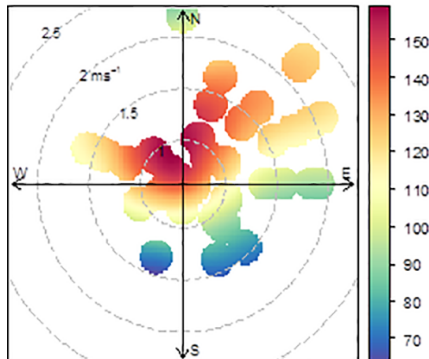

Flt

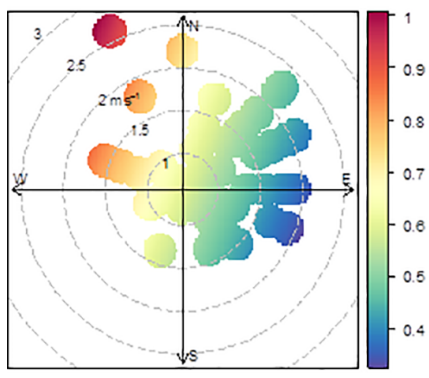

$\mathrm{OC}$

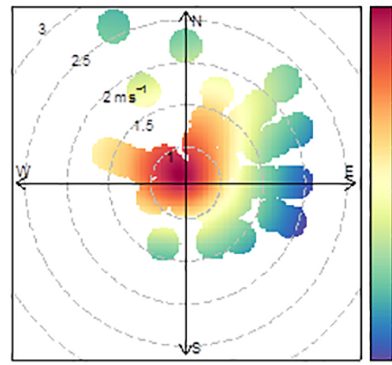

$\mathrm{Cl}^{-}$

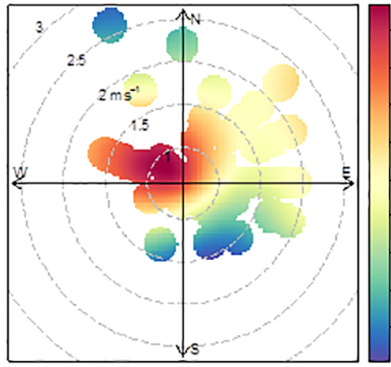

MSA

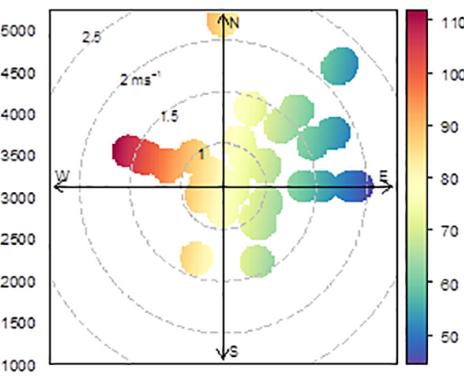

Al

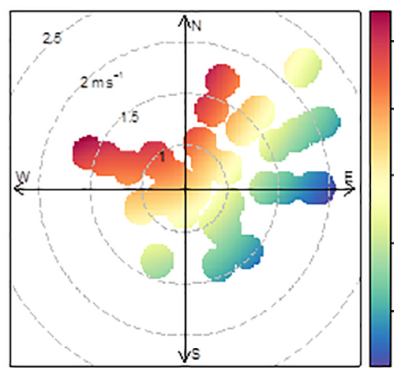

Chr

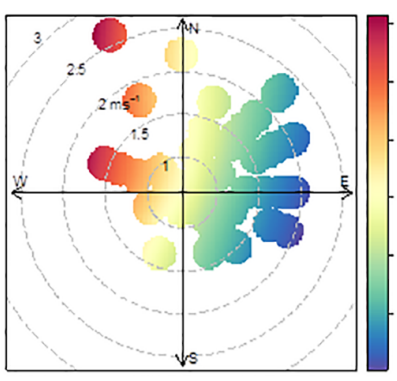

$\mathrm{EC}$

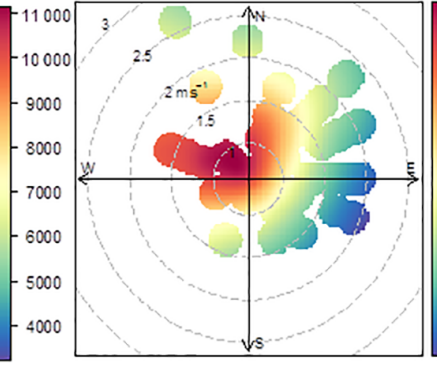

$\mathrm{NO}_{3}{ }^{-}$

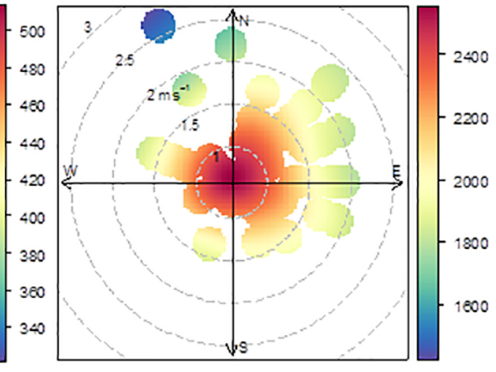

$\mathrm{Na}^{+}$

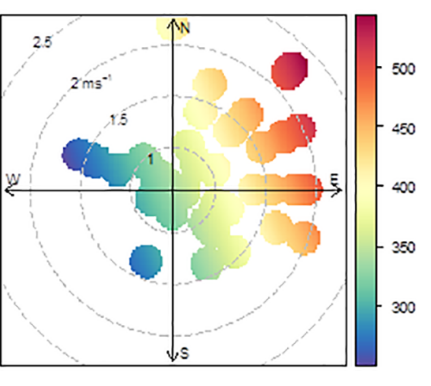

$\mathrm{Ca}$
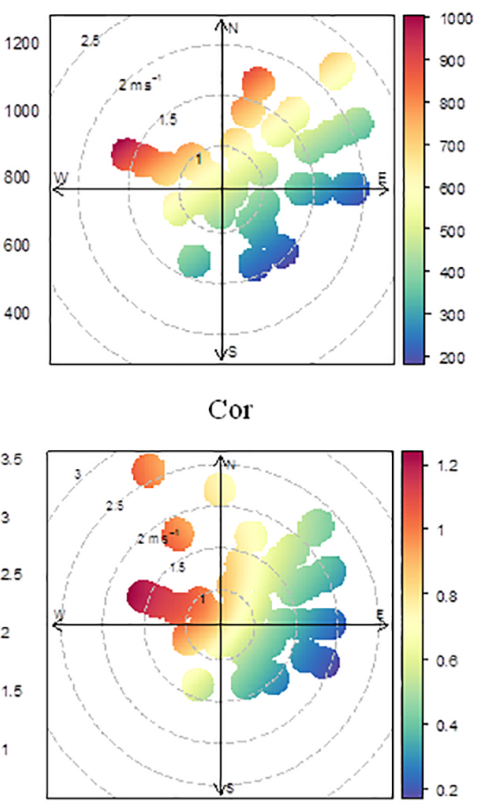

PM

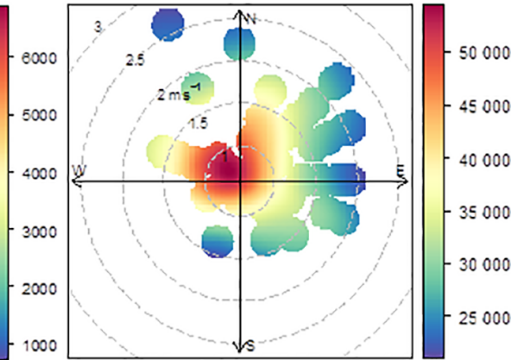

Figure 11. Polar plots for different species ( $\mathrm{ng} \mathrm{m}^{-3}$ and $\mathrm{m} \mathrm{s}^{-1}$ ). 
Good correlations were found between the monosaccharides and $\mathrm{OC}$ and EC, highlighting their contributions to carbonaceous species. Non-sea salt potassium was also well correlated with the biomass burning species, corroborating the input from this source.

PMF analysis was performed and source profiles were obtained for $\mathrm{Int}_{2.5}, \mathrm{Ext}_{2.5}$ and $\mathrm{Ext}_{10}$. Five factors were identified: road dust, industrial, vehicular, biomass burning and secondary processes. Almost $20 \%$ of biomass burning contribution was observed for the $\mathrm{PM}_{2.5}$ intensive sampling campaign. The source apportionment led to the identification of traffic-related sources, as expected for the site, since the samples were collected during weekdays. The considerable biomass burning contribution suggests not only the importance of long-range transport of emissions from sugarcane burning but also the input from local biomass burning sources, such as waste burning and wood stoves in restaurants. More studies are needed on the impact of local sources of biomass burning in order to identify the different inputs.

Data availability. All data are available from the authors Guilherme Martins Pereira (martinspereira2@hotmail.com) and Pérola de Castro Vasconcellos (perola@iq.usp.br). Meteorological data can be found at CETESB, 2014, bulletin (http://www.estacao.iag. usp.br/Boletins/2014.pdf). Gaseous species concentration can be found at CETESB (http://sistemasinter.cetesb.sp.gov.br/Ar/php/ar_ dados_horarios.php).

\section{The Supplement related to this article is available online at https://doi.org/10.5194/acp-17-11943-2017- supplement.}

Author contributions. GMP performed the PAH analysis, WSI and monosaccharide determination, and the PMF analysis, and PV is his advisor and laboratory supervisor in Brazil. KT was responsible for WSI and monosaccharide determination with GMP, and RH was the laboratory supervisor. DC was responsible for carbonaceous species determination and polar plots; CA is the department supervisor in Portugal. AGS developed the method for PAH determination; GOdR and JBdA are the supervisors at UFBA. PK and MdFA contributed to source apportionment. $\mathrm{HX}$ and $\mathrm{RB}$ were responsible for element determination.

Competing interests. The authors declare that they have no conflict of interest.

Acknowledgements. This work was supported by grants from FAPESP, São Paulo Research Foundation and CNPq (project 152601/2013-9); the National Council for Scientific and Technological Development for the postgraduate scholarship and Santander Bank for an international scholarship in Helsinki, Finland. The authors also thank INCT Energy and Environment.
Prashant Kumar also acknowledges the collaborative funding received by the Universities of Surrey and São Paulo through the UGPN-funded projects BIOBURN (Towards the Treatment of Aerosol Emissions from Biomass Burning in Chemical Transport Models through a case study in the Metropolitan Area of São Paulo) and NEST-SEAS (Next-Generation Environmental Sensing for Local to Global Scale Health Impact Assessment) that allowed Guilherme Martins Pereira to work at the University of Surrey, United Kingdom. Pérola de Castro Vasconcellos, Gisele Olímpio da Rocha and Jailson Bittencourt de Andrade thank CNPq for their fellowships. Aldenor Gomes Santos, Gisele Olímpio da Rocha and Jailson Bittencourt de Andrade also thank CAPES, CNPq, FAPESB, FINEP and PETROBRAS for research funding at UFBA. Finally, Gisele Olímpio da Rocha is thankful for partial fellowship funding from Fundação Lehmann. Guilherme Martins Pereira also thanks Ioar Rivas and students Bruna Segalin and Fatima Khanun for the help with the PMF analysis.

Edited by: Veli-Matti Kerminen

Reviewed by: Daniele Contini and one anonymous referee

\section{References}

Abdel-shafy, H. I. and Mansour, M. S. M.: A review on polycyclic aromatic hydrocarbons: Source, environmental impact, effect on human health and remediation, Egypt. J. Pet., 25, 107123, https://doi.org/10.1016/j.ejpe.2015.03.011, 2016.

Agudelo-Castañeda, D. M. and Teixeira, E. C.: Seasonal changes, identification and source apportionment of PAH in $\mathrm{PM}_{1.0}$, Atmos. Environ., 96, 186-200, https://doi.org/10.1016/j.atmosenv.2014.07.030, 2014.

Albinet, A., Leoz-garziandia, E., Budzinski, H., Villenave, E., and Jaffrezo, J.: Nitrated and oxygenated derivatives of polycyclic aromatic hydrocarbons in the ambient air of two French alpine valleys - Part 1: Concentrations, sources and gas/particle partitioning, Atmos. Environ., 42, 43-54, https://doi.org/10.1016/j.atmosenv.2007.10.009, 2008.

Allen, A. G., Cardoso, A. A., and da Rocha, G. O.: Influence of sugar cane burning on aerosol soluble ion composition in Southeastern Brazil, Atmos. Environ., 38, 5025-5038, https://doi.org/10.1016/j.atmosenv.2004.06.019, 2004.

Alonso, M. F., Longo, K. M., Freitas, S. R., Mello da Fonseca, R., Marécal, V., Pirre, M., and Klenner, L. G.: An urban emissions inventory for South America and its application in numerical modeling of atmospheric chemical composition at local and regional scales, Atmos. Environ., 44, 5072-5083, https://doi.org/10.1016/j.atmosenv.2010.09.013, 2010.

Alvarez, H. B., Echeverria, R. S., Alvarez, P. S., and Krupa, S.: Air Quality Standards for Particulate Matter (PM) at high altitude cities, Environ. Pollut., 173, 255-256, https://doi.org/10.1016/j.envpol.2012.09.025, 2013.

Alves, C. A., Gomes, J., Nunes, T., Duarte, M., Calvo, A., Custódio, D., Pio, C., Karanasiou, A., and Querol, X.: Sizesegregated particulate matter and gaseous emissions from motor vehicles in a road tunnel, Atmos. Res., 153, 134-144, https://doi.org/10.1016/j.atmosres.2014.08.002, 2015.

Alves, C. A., Oliveira, C., Martins, N., Mirante, F., Caseiro, A., Pio, C., Matos, M., Silva, H. F., Oliveira, 
C., and Camões, F.: Road tunnel, roadside, and urban background measurements of aliphatic compounds in sizesegregated particulate matter, Atmos. Res., 168, 139-148, https://doi.org/10.1016/j.atmosres.2015.09.007, 2016.

Amato, F., Alastuey, A., Karanasiou, A., Lucarelli, F., Nava, S., Calzolai, G., Severi, M., Becagli, S., Gianelle, V. L., Colombi, C., Alves, C., Custódio, D., Nunes, T., Cerqueira, M., Pio, C., Eleftheriadis, K., Diapouli, E., Reche, C., Minguillón, M. C., Manousakas, M.-I., Maggos, T., Vratolis, S., Harrison, R. M., and Querol, X.: AIRUSE-LIFE+: a harmonized PM speciation and source apportionment in five southern European cities, Atmos. Chem. Phys., 16, 3289-3309, https://doi.org/10.5194/acp16-3289-2016, 2016.

Andrade, M. de F., Orsini, C., and Maenhaut, W.: Relation between aerosol sources and meteorological parameters for inhable atmospheric particles in São Paulo city, Brazil, Atmos. Environ., 28, 2307-2309, https://doi.org/10.1016/1352-2310(94)90484-7, 1994.

Andrade, M. de F., Fornaro, A., Freitas, E. D. de, Mazzoli, C. R., Martins, L. D., Boian, C., Oliveira, M. G. L., Peres, J., Carbone, S., Alvalá, P., and Leme, N. P.: Ozone sounding in the Metropolitan Area of São Paulo, Brazil: Wet and dry season campaigns of 2006, Atmos. Environ., 61, 627-640, https://doi.org/10.1016/j.atmosenv.2012.07.083, 2012a.

Andrade, M. de F., Miranda, R. M., Fornaro, A., Kerr, A., Oyama, B., de André, P. A., and Saldiva, P.: Vehicle emissions and $\mathrm{PM}_{2.5}$ mass concentrations in six Brazilian cities, Air Qual. Atmos. Heal., 5, 79-88, https://doi.org/10.1007/s11869-010-01045, 2012b.

Aurela, M., Saarikoski, S., Timonen, H., Aalto, P., Keronen, P., Saarnio, K., Teinilä, K., Kulmala, M., and Hillamo, R.: Carbonaceous aerosol at a forested and an urban background sites in Southern Finland, Atmos. Environ., 45, 1394-1401, https://doi.org/10.1016/j.atmosenv.2010.12.039, 2011.

Bandowe, B. A. M., Meusel, H., Huang, R., Ho, K., Cao, J., Hoffmann, T., and Wilcke, W.: $\mathrm{PM}_{2.5}$-bound oxygenated PAHs, nitro-PAHs and parent-PAHs from the atmosphere of a Chinese megacity: Seasonal variation, sources and cancer risk assessment, Sci. Total Environ., 473-474, 77-87, https://doi.org/10.1016/j.scitotenv.2013.11.108, 2014.

Bardouki, H., Berresheim, H., Vrekoussis, M., Sciare, J., Kouvarakis, G., Oikonomou, K., Schneider, J., and Mihalopoulos, N.: Gaseous (DMS, MSA, $\mathrm{SO}_{2}, \mathrm{H}_{2} \mathrm{SO}_{4}$ and DMSO) and particulate (sulfate and methanesulfonate) sulfur species over the northeastern coast of Crete, Atmos. Chem. Phys., 3, 1871-1886, https://doi.org/10.5194/acp-3-1871-2003, 2003.

Behera, S. N., Cheng, J., Huang, X., Zhu, Q., Liu, P., and Balasubramanian, R.: Chemical composition and acidity of sizefractionated inorganic aerosols of 2013-14 winter haze in Shanghai and associated health risk of toxic elements, Atmos. Environ., 122, 259-271, https://doi.org/10.1016/j.atmosenv.2015.09.053, 2015.

Bisht, D. S., Dumka, U. C., Kaskaoutis, D. G., Pipal, A. S., Srivastava, A. K., Soni, V. K., Attri, S. D., Sateesh, M., and Tiwari, S.: Carbonaceous aerosols and pollutants over Delhi urban environment: Temporal evolution, source apportionment and radiative forcing, Sci. Total Environ., 521-522, 431-445, https://doi.org/10.1016/j.scitotenv.2015.03.083, 2015.
Bourotte, C., Forti, M.-C., Taniguchi, S., Bícego, M. C., and Lotufo, P. A.: A wintertime study of PAHs in fine and coarse aerosols in São Paulo city, Brazil, Atmos. Environ., 39, 3799-3811, https://doi.org/10.1016/j.atmosenv.2005.02.054, 2005.

Bourotte, C. L. M., Sanchez-Ccoyllo, O. R., Forti, M. C., and Melfi, A. J.: Chemical composition of atmospheric particulate matter soluble fraction and meteorological variables in São Paulo state, Brazil, Rev. Bras. Meteorol., 26, 419-432, https://doi.org/10.1590/S0102-77862011000300008, 2011.

Brito, J., Rizzo, L. V., Herckes, P., Vasconcellos, P. C., Caumo, S. E. S., Fornaro, A., Ynoue, R. Y., Artaxo, P., and Andrade, M. F.: Physical-chemical characterisation of the particulate matter inside two road tunnels in the São Paulo Metropolitan Area, Atmos. Chem. Phys., 13, 12199-12213, https://doi.org/10.5194/acp-13-12199-2013, 2013.

Brown, S. G., Eberly, S., Paatero, P., and Norris, G. A.: Methods for estimating uncertainty in PMF solutions: examples with ambient air and water quality data and guidance on reporting PMF results, Sci. Total Environ., 518-519, 626-635, https://doi.org/10.1016/j.scitotenv.2015.01.022, 2015.

Cabello, M., Orza, J. A. G., Dueñas, C., Liger, E., Gordo, E., and Cañete, S.: Back-trajectory analysis of African dust outbreaks at a coastal city in southern Spain?: Selection of starting heights and assessment of African and concurrent Mediterranean contributions, Atmos. Environ., 140, 10-21, https://doi.org/10.1016/j.atmosenv.2016.05.047, 2016.

Cai, Y., Shao, Y., and Wang, C.: The association of air pollution with the patients' visits to the department of respiratory diseases, J. Clin. Med. Res., 7, 551-555, https://doi.org/10.14740/jocmr2174e, 2015.

Calvo, A. I., Alves, C., Castro, A., Pont, V., Vicente, A. M., and Fraile, R.: Research on aerosol sources and chemical composition: Past, current and emerging issues, Atmos. Res., 120-121, 1-28, https://doi.org/10.1016/j.atmosres.2012.09.021, 2013.

Cançado, J. E. D., Saldiva, P. H. N., Pereira, L. A. A., Lara, L. B. L. S., Artaxo, P., Martinelli, L. A., Arbex, M. A., Zanobetti, A., and Braga, A. L. F.: The impact of sugar cane-burning emissions on the respiratory system of children and the elderly, Environ. Health Perspect., 114, 725-729, https://doi.org/10.1289/ehp.8485, 2006.

Castanho, A. D. A. and Artaxo, P.: Wintertime and summertime São Paulo aerosol source apportionment study, Atmos. Environ., 35, 4889-4902, https://doi.org/10.1016/S1352-2310(01)00357$0,2001$.

Caumo, S., Claeys, M., and Maenhaut, W.: Physicochemical characterization of winter $\mathrm{PM}_{10}$ aerosol impacted by sugarcane burning from São Paulo city , Brazi, Atmos. Environ., 145, 272-279, https://doi.org/10.1016/j.atmosenv.2016.09.046, 2016.

CETESB: Companhia de Tecnologia do Saneamento Ambiental: Relatório de qualidade do ar no Estado de São Paulo 2014, Report of air quality in the São Paulo State 2014, São Paulo, Brazil, available at: http://ar.cetesb.sp.gov.br/ publicacoes-relatorios/ (last access: 1 August 2016), 2015.

Chen, F., Hu, W., and Zhong, Q.: Emissions of particle-phase polycyclic aromatic hydrocarbons (PAHs) in the $\mathrm{Fu}$ Guishan Tunnel of Nanjing, China, Atmos. Res., 124, 53-60, https://doi.org/10.1016/j.atmosres.2012.12.008, 2013.

Chen, W. and Zhu, T.: Formation of nitroanthracene and anthraquinone from the heterogeneous reaction between $\mathrm{NO}_{2}$ and 
anthracene adsorbed on $\mathrm{NaCl}$ particles, Environ. Sci. Technol., 48, 8671-8678, https://doi.org/10.1021/es501543g, 2014.

Chen, Y.-C., Chiang, H.-C., Hsu, C.-Y., Yang, T.-T., Lin, T.Y., Chen, M.-J., Chen, N.-T., and Wu, Y.-S.: Ambient PM $2.5^{-}$ bound polycyclic aromatic hydrocarbons (PAHs) in Changhua County, central Taiwan: Seasonal variation, source apportionment and cancer risk assessment, Environ. Pollut., 218, 118-128, https://doi.org/10.1016/j.envpol.2016.07.016, 2016.

Cheng, S., Yang, L., Zhou, X., Xue, L., Gao, X., Zhou, Y., and Wang, W.: Size-fractionated water-soluble ions, situ $\mathrm{pH}$ and water content in aerosol on hazy days and the influences on visibility impairment in Jinan, China, Atmos. Environ., 45, 4631-4640, https://doi.org/10.1016/j.atmosenv.2011.05.057, 2011.

Cincinelli, A., Del, M., Martellini, T., Gambaro, A., and Lepri, L.: Gas-particle concentration and distribution of n-alkanes and polycyclic aromatic hydrocarbons in the atmosphere of Prato (Italy), Chemosphere, 68, 472-478, https://doi.org/10.1016/j.chemosphere.2006.12.089, 2007.

CONAMA: Padrões de qualidade do Ar, Resolução CONAMA No. 3/1990, available at: http://www. mma.gov.br/cidades-sustentaveis/qualidade-do-ar/

padroes-de-qualidade-do-ar (last access: 1 April 2016), 1990.

Contini, D., Cesari, D., Conte, M., and Donateo, A.: Application of PMF and CMB receptor models for the evaluation of the contribution of a large coal-fired power plant to $\mathrm{PM}_{10}$ concentrations, Sci. Total Environ., 560-561, 131-140, https://doi.org/10.1016/j.scitotenv.2016.04.031, 2016.

Cui, M., Chen, Y., Tian, C., Zhang, F., Yan, C., and Zheng, M.: Chemical composition of $\mathrm{PM}_{2.5}$ from two tunnels with different vehicular fleet characteristics, Sci. Total Environ., 550, 123-132, https://doi.org/10.1016/j.scitotenv.2016.01.077, 2016.

Custódio, D., Cerqueira, M., Alves, C., Nunes, T., Pio, C., Esteves, V., Frosini, D., Lucarelli, F., and Querol, X.: A one-year record of carbonaceous components and major ions in aerosols from an urban kerbside location in Oporto, Portugal, Sci. Total Environ., 562, 822-833, https://doi.org/10.1016/j.scitotenv.2016.04.012, 2016.

da Rocha, G. O., Allen, A. G., and Cardoso, A.: Influence of Agricultural Biomass Burning on Aerosol Size Distribution and Dry Deposition in Southeastern Brazil, Environ. Sci. Technol., 39, 5293-5301, https://doi.org/10.1021/es048007u, 2005.

da Rocha, G. O., Vasconcellos, P. de C., Ávila, S. G., Souza, D. Z., Reis, E. A. O., Oliveira, P. V., and Sanchez-Ccoyllo, O.: Seasonal distribution of airborne trace elements and water-soluble ions in São Paulo Megacity, Brazil, J. Braz. Chem. Soc., 23, 1915-1924, https://doi.org/10.1590/S0103-50532012005000062, 2012.

de Abrantes, R., de Assunção, J. V., and Pesquero, C. R.: Emission of polycyclic aromatic hydrocarbons from lightduty diesel vehicles exhaust, Atmos. Environ., 38, 1631-1640, https://doi.org/10.1016/j.atmosenv.2003.11.012, 2004.

Decesari, S., Fuzzi, S., Facchini, M. C., Mircea, M., Emblico, L., Cavalli, F., Maenhaut, W., Chi, X., Schkolnik, G., Falkovich, A., Rudich, Y., Claeys, M., Pashynska, V., Vas, G., Kourtchev, I., Vermeylen, R., Hoffer, A., Andreae, M. O., Tagliavini, E., Moretti, F., and Artaxo, P.: Characterization of the organic composition of aerosols from Rondônia, Brazil, during the LBA-SMOCC 2002 experiment and its representation through model compounds, Atmos. Chem. Phys., 6, 375-402, https://doi.org/10.5194/acp-6-375-2006, 2006.

de Oliveira Alves, N., Hacon, S. de S., Galvão, M. F. de O., Peixoto, M. S., Artaxo, P., Vasconcellos, P. de C., and de Medeiros, S. R. B.: Genetic damage of organic matter in the Brazilian Amazon: A comparative study between intense and moderate biomass burning, Environ. Res., 130, 51-58, https://doi.org/10.1016/j.envres.2013.12.011, 2014.

de Oliveira Alves, N., Brito, J., Caumo, S., Arana, A., Hacon, S. de S., Artaxo, P., Hillamo, R., Teinilä, K., de Medeiros, S. R. B., and Vasconcellos, P. de C.: Biomass burning in the Amazon region: Aerosol source apportionment and associated health risk assessment, Atmos. Environ., 120, 277-285, https://doi.org/10.1016/j.atmosenv.2015.08.059, 2015.

Draper, W. M.: Quantitation of nitro- and dinitropol ycyclic aromatic hydrocarbons in diesel exhaust particulate matter, Chemosphere, 15, 437-447, https://doi.org/10.1016/00456535(86)90537-0, 1986.

Draxler, R. and Rolph, G.: HYSPLIT (Hybrid Single-Particle Lagrangian Integrated Trajectory) model, NOAA Air Resour. Lab., Silver Spring, MD, available at: http://www.arl.noaa.gov/ready/ hysplit4.html (last access: 1 June 2016), 2003.

Duan, J., Bi, X., Tan, J., Sheng, G., and Fu, J.: Seasonal variation on size distribution and concentration of PAHs in Guangzhou city, China, Chemosphere, 67, 614-622, https://doi.org/10.1016/j.chemosphere.2006.08.030, 2007.

EEA (European Environmental Agency): Air Quality in Europe 2016 Report, EEA Report No 28/2016, Published by Publications Office of the European Union, 2016, ISBN 978-92-9213824-0, 2016.

Franco, A., Kummrow, F., Umbuzeiro, G. A., Vasconcellos, P. de C., and de Carvalho, L. R.: Occurrence of polycyclic aromatic hydrocarbons derivatives and mutagenicitys study in extracts of $\mathrm{PM}_{10}$ collected in São Paulo, Brazil, Rev. Bras. Toxicol., 23, 110, 2010.

Fujimoto, T., Kitamura, S., Sanoh, S., Sugihara, K., Yoshihara, S., Fujimoto, N., and Ohta, S.: Estrogenic activity of an environmental pollutant, 2-nitrofluorene, after metabolic activation by rat liver microsomes, Biochem. Biophys. Res. Commun., 303, 419426, https://doi.org/10.1016/S0006-291X(03)00311-5, 2003.

Godoy, M. L. D. P., Godoy, J. M., Roldão, L. A., Soluri, D. S., and Donagemma, R. A.: Coarse and fine aerosol source apportionment in Rio de Janeiro, Brazil, Atmos. Environ., 43, 2366-2374, https://doi.org/10.1016/j.atmosenv.2008.12.046, 2009.

Gregoris, E., Argiriadis, E., Vecchiato, M., Zambon, S., De Pieri, S., Donateo, A., Contini, D., Piazza, R., Barbante, C., and Gambaro, A.: Science of the Total Environment Gas-particle distributions, sources and health effects of polycyclic aromatic hydrocarbons (PAHs), polychlorinated biphenyls (PCBs) and polychlorinated naphthalenes (PCNs) in Venice aerosols, Sci. Total Environ., 476-477, 393-405, https://doi.org/10.1016/j.scitotenv.2014.01.036, 2014.

Hall, D., Wu, C.-Y., Hsu, Y.-M., Stormer, J., Engling, G., Capeto, K., Wang, J., Brown, S., Li, H.-W., and Yu, K.-M.: PAHs, carbonyls, VOCs and $\mathrm{PM}_{2.5}$ emission factors for pre-harvest burning of Florida sugarcane, Atmos. Environ., 55, 164-172, https://doi.org/10.1016/j.atmosenv.2012.03.034, 2012.

Hidy, G. M.: Surface-Level Fine Particle Mass Concentrations: From Hemispheric Distributions to Megacity Sources Surface- 
Level Fine Particle Mass Concentrations: From Hemispheric Distributions to Megacity Sources, J. Air Waste Manage. Assoc., 59, 770-789, https://doi.org/10.3155/1047-3289.59.7.770, 2009.

IAG: IAG/USP Annual Meteorological Bulletin - 2014, available at: http://www.estacao.iag.usp.br/Boletins/2014.pdf (last access: 1 April 2016), 2014.

INPE: INPE (Instituto Nacional de Pesquisas Espaciais) - Portal do Monitoramento de Queimadas, available at: https://queimadas. dgi.inpe.br/queimadas/ (last access: 1 April 2016), 2014.

Jung, J., Lee, H., Kim, Y. J., Liu, X., Zhang, Y., Gu, J., and Fan, S.: Aerosol chemistry and the effect of aerosol water content on visibility impairment and radiative forcing in Guangzhou during the 2006 Pearl River Delta campaign, J. Environ. Manage., 90, 3231-3244, https://doi.org/10.1016/j.jenvman.2009.04.021, 2009.

Jung, K. H., Yan, B., Chillrud, S. N., Perera, F. P., Whyatt, R., Camann, D., Kinney, P. L., and Miller, R. L.: Assessment of Benzo(a)pyrene-equivalent Carcinogenicity and mutagenicity of residential indoor versus outdoor polycyclic aromatic hydrocarbons exposing young children in New York city, Int. J. Environ. Res. Public Health, 7, 1889-1900, https://doi.org/10.3390/ijerph7051889, 2010.

Karanasiou, A. A., Siskos, P. A., and Eleftheriadis, K.: Assessment of source apportionment by Positive Matrix Factorization analysis on fine and coarse urban aerosol size fractions, Atmos. Environ., 43, 3385-3395, https://doi.org/10.1016/j.atmosenv.2009.03.051, 2009.

Kassomenos, P. A., Vardoulakis, S., Chaloulakou, A., Paschalidou, A. K., Grivas, G., Borge, R., and Lumbreras, J.: Study of $\mathrm{PM}_{10}$ and $\mathrm{PM}_{2.5}$ levels in three European cities: Analysis of intra and inter urban variations, Atmos. Environ., 87, 153-163, https://doi.org/10.1016/j.atmosenv.2014.01.004, 2014.

Khoder, M. I. and Hassan, S. K.: Weekday/weekend differences in ambient aerosol level and chemical characteristics of water-soluble components in the city centre, Atmos. Environ., 42, 7483-7493, https://doi.org/10.1016/j.atmosenv.2008.05.068, 2008.

Kojima, Y., Inazu, K., Hisamatsu, Y., Okochi, H., Baba, T., and Nagoya, T.: Comparison of Pahs, Nitro-Pahs and Oxy-Pahs Associated With Airborne Particulate Matter At Roadside and Urban Background Sites in Downtown Tokyo, Japan, Polycycl. Aromat. Compd., 30, 321-333, https://doi.org/10.1080/10406638.2010.525164, 2010.

Kumar, A. and Attri, A. K.: Biomass Combustion a Dominant Source of Carbonaceous Aerosols in the Ambient Environment of Western Himalayas, Aerosol Air Qual. Res., 16, 519-529, https://doi.org/10.4209/aaqr.2015.05.0284, 2016.

Kumar, P., Morawska, L., Birmili, W., Paasonen, P., Hu, M., Kulmala, M., Harrison, R. M., Norford, L., and Britter, R.: Ultra fine particles in cities, Environ. Int., 66, 1-10, https://doi.org/10.1016/j.envint.2014.01.013, 2014.

Kumar, P., Andrade, M. de F., Ynoue, R. Y., Fornaro, A., de Freitas, E. D., Martins, J., Martins, L. D., Albuquerque, T., Zhang, Y., and Morawska, L.: New directions: From biofuels to wood stoves: The modern and ancient air quality challenges in the megacity of São Paulo, Atmos. Environ., 140, 364-369, https://doi.org/10.1016/j.atmosenv.2016.05.059, 2016.

Kundu, S., Kawamura, K., Andreae, T. W., Hoffer, A., and Andreae, M. O.: Diurnal variation in the water-soluble inorganic ions, organic carbon and isotopic compositions of total carbon and nitrogen in biomass burning aerosols from the LBA-SMOCC campaign in Rondônia, Brazil, J. Aerosol Sci., 41, 118-133, https://doi.org/10.1016/j.jaerosci.2009.08.006, 2010.

de La Torre-Roche, R. J., Lee, W. Y., and Campos-Díaz, S. I.: Soil-borne polycyclic aromatic hydrocarbons in $\mathrm{El}$ Paso, Texas: analysis of a potential problem in the United States/Mexico border region, J. Hazard. Mater., 163, 946-958, https://doi.org/10.1016/j.jhazmat.2008.07.089, 2009.

Lang, Y.-H., Li, G., Wang, X.-M., and Peng, P.: Combination of Unmix and PMF receptor model to apportion the potential sources and contributions of PAHs in wetland soils from Jiaozhou Bay, China, Mar. Pollut. Bull., 90, 129-134, https://doi.org/10.1016/j.marpolbul.2014.11.009, 2015.

Lee, J. D.: Concise Inorganic Chemistry, 5th Edn., Willey, 1070 pp., 1999.

Liu, B., Bi, X., Feng, Y., Dai, Q., Xiao, Z., Li, L., Wu, J., Yuan, J., and Zhang, Y.: Fine carbonaceous aerosol characteristics at a megacity during the Chinese Spring Festival as given by OC / EC online measurements, Atmos. Res., 181, 20-28, https://doi.org/10.1016/j.atmosres.2016.06.007, 2016.

Maenhaut, W., Raes, N., Chi, X., Cafmeyer, J., and Wang, W.: Chemical composition and mass closure for $\mathrm{PM}_{2.5}$ and $\mathrm{PM}_{10}$ aerosols at K-puszta, Hungary, in summer 2006, X-Ray Spectrom., 37, 193-197, https://doi.org/10.1002/xrs.1062, 2008.

Maenhaut, W., Vermeylen, R., Claeys, M., Vercauteren, J., and Roekens, E.: Sources of the $\mathrm{PM}_{10}$ aerosol in Flanders, Belgium, and re-assessment of the contribution from wood burning, Sci. Total Environ., 562, 550-560, https://doi.org/10.1016/j.scitotenv.2016.04.074, 2016.

de Martinis, B. S., Okamoto, R. A., Kado, N. Y., Gundel, L. A., and Carvalho, L. R. F.: Polycyclic aromatic hydrocarbons in a bioassay-fractionated extract of $\mathrm{PM}_{10}$ collected in São Paulo, Brazil, Atmos. Environ., 36, 307-314, https://doi.org/10.1016/S1352-2310(01)00334-X, 2002.

Miguel, A. H., Kirchstetter, T. W., Harley, R. A., and Hering, S. V.: On-road emissions of particulate polycyclic aromatic hydrocarbons and black carbon from gasoline and diesel vehicles, Environ. Sci. Technol., 32, 450-455, https://doi.org/10.1021/es970566w, 1998.

Miranda, R. M. de, Andrade, M. de F., Fornaro, A., Astolfo, R., de André, P. A., and Saldiva, P.: Urban air pollution: A representative survey of $\mathrm{PM}_{2.5}$ mass concentrations in six Brazilian cities, Air Qual. Atmos. Heal., 5, 63-77, https://doi.org/10.1007/s11869-010-0124-1, 2012.

Mirante, F., Alves, C., Pio, C., Pindado, O., Perez, R., Revuelta, M. A., and Artiñano, B.: Organic composition of size segregated atmospheric particulate matter, during summer and winter sampling campaigns at representative sites in Madrid, Spain, Atmos. Res., 132-133, 345-361, https://doi.org/10.1016/j.atmosres.2013.07.005, 2013.

Mkoma, S. L., da Rocha, G. O., Regis, A. C. D., Domingos, J. S. S., Santos, J. V. S., de Andrade, S. J., Carvalho, L. S., and De Andrade, J. B.: Major ions in $\mathrm{PM}_{2.5}$ and $\mathrm{PM}_{10}$ released from buses: The use of diesel/biodiesel fuels under real conditions, Fuel, 115, 109-117, https://doi.org/10.1016/j.fuel.2013.06.044, 2014.

MMA: Ministerio del Medio Ambiente (MMA) Progress Report on Santiago's Pollution Prevention Plan, available at: http://www.sinia.cl/1292/articles-55841_ 
InformeFINALSeguimientoPPDA2012_RM.pdf (last access: 1 April 2016), 2014 (in Spanish).

Nayebare, S. R., Aburizaiza, O. S., Khwaja, H. A., Siddique, A., Hussain, M. M., Zeb, J., Khatib, F., Carpenter, D. O., and Blake, D. R.: Chemical Characterization and Source Apportionment of $\mathrm{PM}_{2.5}$ in Rabigh, Saudi Arabia, Aerosol Air Qual. Res., 16, 3114-3129, https://doi.org/10.4209/aaqr.2015.11.0658, 2016.

Newby, D. E., Mannucci, P. M., Tell, G. S., Baccarelli, A. A., Brook, R. D., Donaldson, K., Forastiere, F., Franchini, M., Franco, O. H., Graham, I., Hoek, G., Hoffmann, B., Hoylaerts, M. F., Künzli, N., Mills, N., Pekkanen, J., Peters, A., Piepoli, M. F., Rajagopalan, S., and Storey, R. F.: Expert position paper on air pollution and cardiovascular disease, Eur. Heart J., 36, 83-93, https://doi.org/10.1093/eurheartj/ehu458, 2015.

Norris, G., Duvall, R., Brown, S., and Bai, S.: EPA Positive Matrix Factorization (PMF) 5.0 Fundamentals and User Guide, available at: https://www.epa.gov/air-research/ epa-positive-matrix-factorization-50-fundamentals-and-user-guide (last access: 1 August 2016), 2014.

Oliveira, C., Martins, N., Tavares, J., Pio, C., Cerqueira, M., Matos, M., Silva, H., Oliveira, C., and Camões, F.: Size distribution of polycyclic aromatic hydrocarbons in a roadway tunnel in Lisbon, Portugal, Chemosphere, 83, 1588-1596, https://doi.org/10.1016/j.chemosphere.2011.01.011, 2011.

Oyama, B. S., Andrade, M. D. F., Herckes, P., Dusek, U., Röckmann, T., and Holzinger, R.: Chemical characterization of organic particulate matter from on-road traffic in São Paulo, Brazil, Atmos. Chem. Phys., 16, 14397-14408, https://doi.org/10.5194/acp-16-14397-2016, 2016.

Paatero, P. and Hopke, P. K.: Discarding or downweighting highnoise variables in factor analytic models, Anal. Chim. Acta, 490, 277-289, https://doi.org/10.1016/S0003-2670(02)01643-4, 2003.

Paatero, P. and Tapper, U.: Positive matrix factorization: A non-negative factor model with optimal utilization of error estimates of data values, Environmetrics, 5, 111-126, https://doi.org/10.1002/env.3170050203, 1994.

Pacheco, M. T., Parmigiani, M. M. M., Andrade, M. de F., Morawska, L., and Kumar, P.: A review of emissions and concentrations of particulate matter in the three major metropolitan areas of Brazil, J. Transp. Heal., 4, 53-72, https://doi.org/10.1016/j.jth.2017.01.008, 2017.

Pereira, P. A. de P., Lopes, W. A., Carvalho, L. S., da Rocha, G. O., Carvalho, N. De, Loyola, J., Quiterio, S. L., Escaleira, V., Arbilla, G., and de Andrade, J. B.: Atmospheric concentrations and dry deposition fluxes of particulate trace metals in Salvador, Bahia, Brazil, Atmos. Environ., 41, 7837-7850, https://doi.org/10.1016/j.atmosenv.2007.06.013, 2007.

Pereira, G. M., Alves, N. O., Caumo, S. E. S., Soares, S., Teinilä, K., Custódio, D., Hillamo, R., Alves, C., and Vasconcellos, P. C.: Chemical composition of aerosol in São Paulo, Brazil: Influence of the transport of pollutants, Air Qual. Atmos. Heal., 10, 457468, https://doi.org/10.1007/s11869-016-0437-9, 2017.

Pio, C. A., Legrand, M., Alves, C. A., Oliveira, T., Afonso, J., Caseiro, A., Puxbaum, H., Sanchez-Ochoa, A., and Gelencsér, A.: Chemical composition of atmospheric aerosols during the 2003 summer intense forest fire period, Atmos. Environ., 42, 75307543, https://doi.org/10.1016/j.atmosenv.2008.05.032, 2008.
Pio, C. A., Cerqueira, M., Harrison, R. M., Nunes, T., Mirante, F., Alves, C., Oliveira, C., de la Campa, A. S., Artíñano, B., and Matos, M.: OC / EC ratio observations in Europe: Rethinking the approach for apportionment between primary and secondary organic carbon, Atmos. Environ., 45, 6121-6132, https://doi.org/10.1016/j.atmosenv.2011.08.045, 2011.

Pio, C. A., Mirante, F., Oliveira, C., Matos, M., Caseiro, A., Oliveira, C., Querol, X., Alves, C., Martins, N., Cerqueira, M., Camões, F., Silva, H., and Plana, F.: Size-segregated chemical composition of aerosol emissions in an urban road tunnel in Portugal, Atmos. Environ., 71, 15-25, https://doi.org/10.1016/j.atmosenv.2013.01.037, 2013.

Pope, C. A.: Epidemiology of fine particulate air pollution and human health: Biologic mechanisms and who's at risk?, Environ. Health Perspect., 108, 713-723, https://doi.org/10.1289/ehp.00108s4713, 2000.

Pöschl, U.: Atmospheric aerosols: Composition, transformation, climate and health effects, Angew. Chem. Int. Edit., 44, 7520 7540, https://doi.org/10.1002/anie.200501122, 2005.

Putaud, J. P., Raes, F., Van Dingenen, R., Brüggemann, E., Facchini, M.-C., Decesari, S., Fuzzi, S., Gehrig, R., Hüglin, C., Laj, P., Lorbeer, G., Maenhaut, W., Mihalopoulos, N., Müller, K., Querol, X., Rodriguez, S., Schneider, J., Spindler, G., Brink, H. ten, Tørseth, K., and Wiedensohler, A.: A European aerosol phenomenology - 2:chemical characteristics of particulate matter at kerbside, urban, rural and background sites in Europe, Atmos. Environ., 38, 2579-2595, https://doi.org/10.1016/j.atmosenv.2004.01.041, 2004.

Ram, K., Sarin, M. M., and Tripathi, S. N.: A 1 year record of carbonaceous aerosols from an urban site in the Indo-Gangetic Plain: Characterization, sources, and temporal variability, J. Geophys. Res.-Atmos., 115, 1-14, https://doi.org/10.1029/2010JD014188, 2010.

Rao, P. S. P., Tiwari, S., Matwale, J. L., Pervez, S., Tunved, P., Safai, P. D., Srivastava, A. K., Bisht, D. S., Singh, S., and Hopke, P. K.: Sources of chemical species in rainwater during monsoon and non- monsoonal periods over two mega cities in India and dominant source region of secondary aerosols, Atmos. Environ., 146, 90-99, https://doi.org/10.1016/j.atmosenv.2016.06.069, 2016.

Rastogi, N. and Sarin, M. M.: Quantitative chemical composition and characteristics of aerosols over western India: One-year record of temporal variability, Atmos. Environ., 43, 3481-3488, https://doi.org/10.1016/j.atmosenv.2009.04.030, 2009.

Rastogi, N., Singh, A., Singh, D., and Sarin, M. M.: Chemical characteristics of $\mathrm{PM}_{2.5}$ at a source region of biomass burning emissions: Evidence for secondary aerosol formation, Environ. Pollut., 184, 563-569, https://doi.org/10.1016/j.envpol.2013.09.037, 2014.

Ravindra, K., Bencs, L., Wauters, E., De Hoog, J., Deutsch, F., Roekens, E., Bleux, N., Berghmans, P., and Van Grieken, R.: Seasonal and site-specific variation in vapour and aerosol phase PAHs over Flanders (Belgium) and their relation with anthropogenic activities, Atmos. Environ., 40, 771-785, https://doi.org/10.1016/j.atmosenv.2005.10.011, 2006.

Ravindra, K., Sokhi, R., and Van Grieken, R.: Atmospheric polycyclic aromatic hydrocarbons: Source attribution, emission factors and regulation, Atmos. Environ., 42, 2895-2921, https://doi.org/10.1016/j.atmosenv.2007.12.010, 2008. 
Ringuet, J., Albinet, A., Leoz-Garziandia, E., Budzinski, H., and Villenave, E.: Diurnal/nocturnal concentrations and sources of particulate-bound PAHs, OPAHs and NPAHs at traffic and suburban sites in the region of Paris (France), Sci. Total Environ., 437, 297-305, https://doi.org/10.1016/j.scitotenv.2012.07.072, 2012.

Robbat, A. and Wilton, N. M.: A new spectral deconvolution - Selected ion monitoring method for the analysis of alkylated polycyclic aromatic hydrocarbons in complex mixtures, Talanta, 125, 114-124, https://doi.org/10.1016/j.talanta.2014.02.068, 2014.

Romero-Lankao, P., Qin, H., and Borbor-Cordova, M.: Exploration of health risks related to air pollution and temperature in three Latin American cities, Soc. Sci. Med., 83, 110-118, https://doi.org/10.1016/j.socscimed.2013.01.009, 2013.

Saarnio, K., Teinilä, K., Aurela, M., Timonen, H., and Hillamo, R.: High-performance anion-exchange chromatographymass spectrometry method for determination of levoglucosan, mannosan, and galactosan in atmospheric fine particulate matter, Anal. Bioanal. Chem., 398, 2253-2264, https://doi.org/10.1007/s00216-010-4151-4, 2010.

Sánchez-Ccoyllo, O. R. and Andrade, M. d. F.: The influence of meteorological conditions on the behavior of pollutants concentrations in São Paulo, Brazil, Environ. Pollut., 116, 257-263, https://doi.org/10.1016/S0269-7491(01)00129-4, 2002.

Santos, A. G., Regis, A. C. D., da Rocha, G. O., Bezerra, M. de A., de Jesus, R. M., and de Andrade, J. B.: A simple, comprehensive, and miniaturized solvent extraction method for determination of particulate-phase polycyclic aromatic compounds in air., J. Chromatogr. A, 1435, 6-17, https://doi.org/10.1016/j.chroma.2016.01.018, 2016.

Sarigiannis, D. A., Karakitsios, S. P., Zikopoulos, D., Nikolaki, S., and Kermenidou, M.: Lung cancer risk from PAHs emitted from biomass combustion, Environ. Res., 137, 147-156, https://doi.org/10.1016/j.envres.2014.12.009, 2015.

Schkolnik, G., Falkovich, A. H., Rudich, Y., Maenhaut, W., and Artaxo, P.: New analytical method for the determination of levoglucosan, polyhydroxy compounds, and 2-methylerythritol and its application to smoke and rainwater samples, Environ. Sci. Technol., 39, 2744-2752, https://doi.org/10.1021/es048363c, 2005.

SEADE: SP Demografico - Resenha de Estatísticas Vitais do Estado de São Paulo: Diferenciais regionais de fecundidade no município de São Paulo, available at: http://www.seade. gov.br/produtos/midia/2016/06/N.2_jun2016-final.pdf, last access: 1 August 2016.

Segalin, B., Kumar, P., Micadei, K., Fornaro, A., and Gonçalves, F. L. T.: Size-segregated particulate matter inside residences of elderly in the Metropolitan Area of São Paulo, Brazil, Atmos. Environ., 148, 139-151, https://doi.org/10.1016/j.atmosenv.2016.10.004, 2017.

Seinfeld, J. H. and Pandis, S. N.: Atmospheric Chemistry and Physics: From Air Pollution to Climate Change, 2nd Edn., John Wiley \& Sons, New York, 2006.

Shi, G., Tian, Y., Ye, S., Peng, X., Xu, J., Wang, W., Han, B., and Feng, Y.: Source apportionment of synchronously size segregated fine and coarse particulate matter, using an improved threeway factor analysis model, Sci. Total Environ., 505, 1182-1190, https://doi.org/10.1016/j.scitotenv.2014.10.106, 2015.

Simoneit, B. R. T., Schauer, J. J., Nolte, C. G., Oros, D. R., Elias, V. O., Fraser, M. P., Rogge, W. F., and Cass, G. R.: Levoglucosan, a tracer for cellulose in biomass burning and atmospheric particles,
Atmos. Environ., 33, 173-182, https://doi.org/10.1016/S13522310(98)00145-9, 1999.

Souza, D. Z., Vasconcellos, P. C., Lee, H., Aurela, M., Saarnio, K., Teinilä, K., and Hillamo, R.: Composition of $\mathrm{PM}_{2.5}$ and $\mathrm{PM}_{10}$ collected at Urban Sites in Brazil, Aerosol Air Qual. Res., 14, 168-176, https://doi.org/10.4209/aaqr.2013.03.0071, 2014a.

Souza, K. F., Carvalho, L. R. F., Allen, A. G., and Cardoso, A. A.: Diurnal and nocturnal measurements of PAH, nitro-PAH, and oxy-PAH compounds in atmospheric particulate matter of a sugar cane burning region, Atmos. Environ., 83, 193-201, https://doi.org/10.1016/j.atmosenv.2013.11.007, 2014b.

Tan, J.-H., Duan, J.-C., Chen, D.-H., Wang, X.-H., Guo, S.-J., Bi, X.-H., Sheng, G.-Y., He, K.-B., and Fu, J.M.: Chemical characteristics of haze during summer and winter in Guangzhou, Atmos. Res., 94, 238-245, https://doi.org/10.1016/j.atmosres.2009.05.016, 2009.

Tang, X., Zhang, X., Ci, Z., Guo, J., and Wang, J.: Speciation of the major inorganic salts in atmospheric aerosols of Beijing, China: Measurements and comparison with model, Atmos. Environ., 133, 123-134, https://doi.org/10.1016/j.atmosenv.2016.03.013, 2016.

Teixeira, E. C., Mattiuzi, C. D. P., Agudelo-Castañeda, D. M., Garcia, K. de O., and Wiegand, F.: Polycyclic aromatic hydrocarbons study in atmospheric fine and coarse particles using diagnostic ratios and receptor model in urban/industrial region, Environ. Monit. Assess., 185, 9587-9602, https://doi.org/10.1007/s10661-013-3276-2, 2013.

Timonen, H., Carbone, S., Aurela, M., Saarnio, K., Saarikoski, S., Ng, N. L., Canagaratna, M. R., Kulmala, M., Kerminen, V. M., Worsnop, D. R., and Hillamo, R.: Characteristics, sources and water-solubility of ambient submicron organic aerosol in springtime in Helsinki, Finland, J. Aerosol Sci., 56, 61-77, https://doi.org/10.1016/j.jaerosci.2012.06.005, 2013.

Tiwari, S., Dumka, U. C., Kaskaoutis, D. G., Ram, K., Panicker, A. S., Srivastava, M. K., Tiwari, S., Attri, S. D., Soni, V. K., and Pandey, A. K.: Aerosol chemical characterization and role of carbonaceous aerosol on radiative effect over Varanasi in central Indo-Gangetic Plain, Atmos. Environ., 125, 437-449, https://doi.org/10.1016/j.atmosenv.2015.07.031, 2016.

Tobiszewski, M. and Namieœnik, J.: PAH diagnostic ratios for the identification of pollution emission sources, Environ. Pollut., 162, 110-119, https://doi.org/10.1016/j.envpol.2011.10.025, 2012.

Toledano, C., Cachorro, V. E., Frutos, A. M. de, Torres, B., Berjon, A., Sorribas, M., and Stone, R. S.: Airmass Classification and Analysis of Aerosol Types at El Arenosillo (Spain), J. Appl. Meteorol. Climatol., 48, 962-981, https://doi.org/10.1175/2008JAMC2006.1, 2009.

Urban, R. C., Lima-Souza, M., Caetano-Silva, L., Queiroz, M. E. C., Nogueira, R. F. P., Allen, A. G., Cardoso, A. A., Held, G., and Campos, M. L. A. M.: Use of levoglucosan, potassium, and water-soluble organic carbon to characterize the origins of biomass-burning aerosols, Atmos. Environ., 61, 562-569, https://doi.org/10.1016/j.atmosenv.2012.07.082, 2012.

Urban, R. C., Alves, C. A., Allen, A. G., Cardoso, A. A., Queiroz, M. E. C., and Campos, M. L. A. M.: Sugar markers in aerosol particles from an agroindustrial region in Brazil, Atmos. Environ., 90, 106-112, https://doi.org/10.1016/j.atmosenv.2014.03.034, 2014. 
Urban, R. C., Alves, C. A., Allen, A. G., Cardoso, A. A., and Campos, M. L. A. M.: Organic aerosols in a Brazilian agro-industrial area: Speciation and impact of biomass burning, Atmos. Res., 169, 271-279, https://doi.org/10.1016/j.atmosres.2015.10.008, 2016.

Vara-Vela, A., Andrade, M. F., Kumar, P., Ynoue, R. Y., and Muñoz, A. G.: Impact of vehicular emissions on the formation of fine particles in the Sao Paulo Metropolitan Area: a numerical study with the WRF-Chem model, Atmos. Chem. Phys., 16, 777-797, https://doi.org/10.5194/acp-16-777-2016, 2016.

Vasconcellos, P. C., Zacarias, D., Pires, M. A. F., Pool, C. S., and Carvalho, L. R. F.: Measurements of polycyclic aromatic hydrocarbons in airborne particles from the metropolitan area of São Paulo City, Brazil, Atmos. Environ., 37, 3009-3018, https://doi.org/10.1016/S1352-2310(03)00181-X, 2003.

Vasconcellos, P. C., Balasubramanian, R., Bruns, R. E., SanchezCcoyllo, O., Andrade, M. F., and Flues, M.: Water-soluble ions and trace metals in airborne particles over urban areas of the state of São Paulo, Brazil: Influences of local sources and long range transport, Water. Air. Soil Pollut., 186, 63-73, https://doi.org/10.1007/s11270-007-9465-2, 2007.

Vasconcellos, P. C., Souza, D. Z., Sanchez-Ccoyllo, O., Bustillos, J. O. V, Lee, H., Santos, F. C., Nascimento, K. H., Araújo, M. P., Saarnio, K., Teinilä, K., and Hillamo, R.: Determination of anthropogenic and biogenic compounds on atmospheric aerosol collected in urban, biomass burning and forest areas in São Paulo, Brazil, Sci. Total Environ., 408, 5836-5844, https://doi.org/10.1016/j.scitotenv.2010.08.012, 2010.

Vasconcellos, P. C., Souza, D. Z., Avila, S. G., Araujo, M. P., Naoto, E., Nascimento, K. H., Cavalcante, F. S., Dos Santos, M., Smichowski, P., and Behrentz, E.: Comparative study of the atmospheric chemical composition of three South American cities, Atmos. Environ., 45, 5770-5777, https://doi.org/10.1016/j.atmosenv.2011.07.018, 2011a.

Vasconcellos, P. C., Souza, D. Z., Magalhães, D., and da Rocha, G. O.: Seasonal variation of n-alkanes and polycyclic aromatic hydrocarbon concentrations in $\mathrm{PM}_{10}$ samples collected at urban sites of São Paulo State, Brazil, Water. Air. Soil Pollut., 222, 325336, https://doi.org/10.1007/s11270-011-0827-4, 2011 b.

Vieira-Filho, M., Pedrotti, J. J., and Fornaro, A.: Water-soluble ions species of size-resolved aerosols: Implications for the atmospheric acidity in São Paulo megacity, Brazil, Atmos. Res., 181, 281-287, https://doi.org/10.1016/j.atmosres.2016.07.006, 2016.

Villalobos, A. M., Barraza, F., Jorquera, H., and Schauer, J. J.: Chemical speciation and source apportionment of fine particulate matter in Santiago, Chile, 2013, Sci. Total Environ., 512-513, 133-142, https://doi.org/10.1016/j.scitotenv.2015.01.006, 2015.

Wang, G., Wang, H., Yu, Y., Gao, S., Feng, J., Gao, S., and Wang, L.: Chemical characterization of water-soluble components of $\mathrm{PM}_{10}$ and $\mathrm{PM}_{2.5}$ atmospheric aerosols in five locations of Nanjing, China, Atmos. Environ., 37, 2893-2902, https://doi.org/10.1016/S1352-2310(03)00271-1, 2003.
Wang, J., Hu, Z., Chen, Y., Chen, Z., and Xu, S.: Contamination characteristics and possible sources of $\mathrm{PM}_{10}$ and $\mathrm{PM}_{2.5}$ in different functional areas of Shanghai, China, Atmos. Environ., 68, 221-229, https://doi.org/10.1016/j.atmosenv.2012.10.070, 2013.

Wang, Y., Zhang, Q. Q., He, K., Zhang, Q., and Chai, L.: Sulfate-nitrate-ammonium aerosols over China: response to 2000-2015 emission changes of sulfur dioxide, nitrogen oxides, and ammonia, Atmos. Chem. Phys., 13, 2635-2652, https://doi.org/10.5194/acp-13-2635-2013, 2013.

White, W. H.: Chemical markers for sea salt in IMPROVE aerosol data, Atmos. Environ., 42, 261-274, https://doi.org/10.1016/j.atmosenv.2007.09.040, 2008.

WHO: Air quality guidelines for Europe, WHO Reg. Publ. Eur. Ser. No. 91, 2nd Edn., https://doi.org/10.1007/BF02986808, 2000.

WHO: WHO Air quality guidelines for particulate matter, ozone, nitrogen dioxide and sulfur dioxide: global update 2005: summary of risk assessment, Geneva World Heal. Organ., 1-22, https://doi.org/10.1016/0004-6981(88)90109-6, 2006.

Yang, Y., Zhou, R., Wu, J., Yu, Y., Ma, Z., Zhang, L., and Di, Y.: Seasonal variations and size distributions of water-soluble ions in atmospheric aerosols in Beijing, 2012, J. Environ. Sci., 34, 197-205, https://doi.org/10.1016/j.jes.2015.01.025, 2015.

Yassaa, N., Meklati, B. Y., Cecinato, A., and Marino, F.: Particulate n-alkanes, n-alkanoic acids and polycyclic aromatic hydrocarbons in the atmosphere of Algiers City Area, Atmos. Environ., 35, 1843-1851, https://doi.org/10.1016/S1352-2310(00)005148, 2001.

Yu, G., Zhang, Y., Cho, S., and Park, S.: Influence of haze pollution on water-soluble chemical species in $\mathrm{PM}_{2.5}$ and size-resolved particles at an urban site during fall, J. Environ. Sci., 57, 370382, https://doi.org/10.1016/j.jes.2016.10.018, 2017.

Zheng, J., Hu, M., Peng, J., Wu, Z., Kumar, P., Li, M., Wang, Y., and Guo, S.: Spatial distributions and chemical properties of $\mathrm{PM}_{2.5}$ based on 21 field campaigns at 17 sites in China, Chemosphere, 159, 480-487, https://doi.org/10.1016/j.chemosphere.2016.06.032, 2016.

Zhou, S. and Wenger, J. C.: Kinetics and products of the gasphase reactions of acenaphthylene with hydroxyl radicals, nitrate radicals and ozone, Atmos. Environ., 75, 103-112, https://doi.org/10.1016/j.atmosenv.2013.04.049, 2013.

Zimmermann, K., Jariyasopit, N., Simonich, S. L. M., Tao, S., Atkinson, R., and Arey, J.: Formation of nitro-PAHs from the heterogeneous reaction of ambient particle-bound PAHs with $\mathrm{N}_{2} \mathrm{O}_{5} / \mathrm{NO}_{3} / \mathrm{NO}_{2}$, Environ. Sci. Technol., 47, 8434-8442, https://doi.org/10.1021/es401789x, 2013. 